\title{
Do High Performance Work Systems Always Help to Retain Employees or Is There a Dark Side?
}

\section{Elaheh Behravesh}

Submitted to the

Institute of Graduate Studies and Research

in partial fulfillment of the requirements for the degree of

Doctor of Philosophy

in

Business Administration

Eastern Mediterranean University

July 2019

Gazimağusa, North Cyprus 
Approval of the Institute of Graduate Studies and Research

\section{Prof. Dr. Ali Hakan Ulusoy \\ Acting Director}

I certify that this thesis satisfies all the requirements as a thesis for the degree of Doctor of Philosophy in Business Administration.

Assoc. Prof. Dr. Melek Şule Aker

Chair, Department of Business Administration

We certify that we have read this thesis and that in our opinion it is fully adequate in scope and quality as a thesis for the degree of Doctor of Philosophy in Business Administration.

\footnotetext{
Asst. Prof. Dr. A. Mohammed Abubakar Co-Supervisor
}

\author{
Prof. Dr. Cem Tanova \\ Supervisor
}

Examining Committee

1. Prof. Dr. İbrahim Sani Mert

2. Prof. Dr. Cem Tanova

3. Prof. Dr. Çağatay Ünüsan

4. Assoc. Prof. Dr. İlhan Dalc1

5. Asst. Prof. Dr. Mehmet İslamoğlu 


\begin{abstract}
This study considers both the positive and possible negative impacts of high performance work systems (HPWS) by investigating their relationship with job demands, job satisfaction and job search behavior. The parallel mediation effect of job satisfaction and physiological job demand on the link between HPWS and job search behavior is also examined. Data was collected in two phases from 22 branches of Iranian private banks from 269 employees in 2016. Results from a covariance based structural equation modeling (CB-SEM) shows that HPWS positively relates to job satisfaction, physiological job demand and job search behavior. Job satisfaction negatively relates to job search behavior and also mediates the link between HPWS and job search behavior. However, job demand did not have any mediation effect on the link, which means that employees exposed to high job demand do not necessarily engage in the search for alternative jobs. The results offer practical implications for managers and policy makers in the service industry to balance between job demands - resources in workplace and provide adequate resources for their employees to buffer specific negative effects of job demands.
\end{abstract}

Keywords: Service industry, job satisfaction, job demand, job search behavior. 


\section{$\ddot{O} \mathbf{Z}$}

Çalışmada Yüksek Performanslı İş Sistemlerinin (YPİS) olumlu ve muhtemel olumsuz etkileri iş yükü, iş tatmini, ve iş arama davranışları ile ilişsileri incelenerek ele alınmaktadır. YPİS ve iş arama davranışları arasındaki ilşki üzerinde iş tatmini ve psikolojik iş yükünün aracılık etkisi de incelenmektedir. Veriler iki aşmada İran bankalarından 269 çalışandan 2016 yılında toplanmıştır. Yapısal Eşitleme Modeli kullanılarak yapılan analiz sonucunda YPİS ve iş tatmini, psikolojik iş yükü, iş arama davranışı arasında ilişki olduğu belirlenmiştir. İş tatmini ve iş arama davranışı arasında olumsuz bir ilişki bulunmaktadır ve YPİS ile iş arama davranışı arasındaki ilişkiye de aracılık etmektedir. Ancak, iş yükünün beklenen aracılık etkisi görülmemiştir. Buna göre iş yükü artışı tek başına iş arayışına yol açmamaktadır. Çalışmanın sonuçları, hizmet sektörü yöneticileri için pratik bazı çıkarımlar içermektedir. İş yükünün olumsuz etkilerinden çalışanlarını korumak için artan iş yükü ile kaynaklar arasında bir denge oluşturulması gerekmektedir.

Anahtar Kelimeler: Servis sektörü, İş tatmini, İş yükü, İş arama davranışları. 


\section{ACKNOWLEDGMENT}

The road to $\mathrm{PhD}$ is solid but it's quite worth the struggles at the end of course.

I dedicate my dissertation to all my family members: my father "Mustafa", kind mother "Fatemeh", my brother "Masood", my beautiful sisters "Mahshid and Azar" and my amazing sister's family "Naser, Shaghayegh, and Mahdyar". Your endless love, encouragement and support were with me all the way.

I am also grateful to my brilliant Supervisor, Prof. Dr. Cem Tanova, for his attitude and dedication towards teaching and conducting research. Also, I appreciate my exceptionally talented Co-Supervisor Asst. Prof. Dr. A. Mohammed Abubakar for his ingenious knowledge and endless support.

In addition, I am thankful to the Department of Business Administration of Eastern Mediterranean University, for providing me the precious opportunity to study and teach in this field. 


\section{TABLE OF CONTENTS}

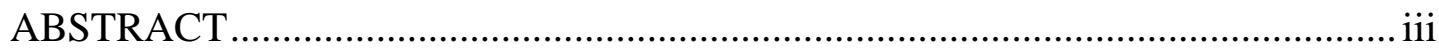

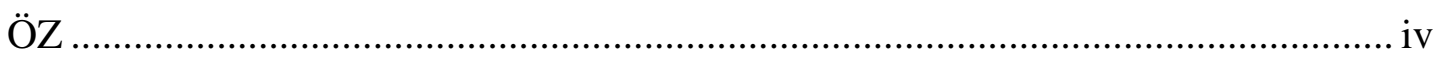

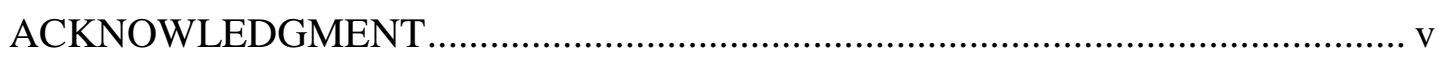

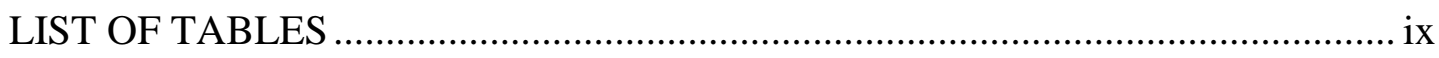

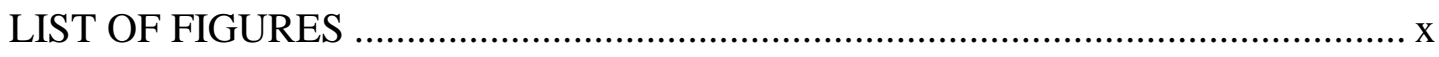

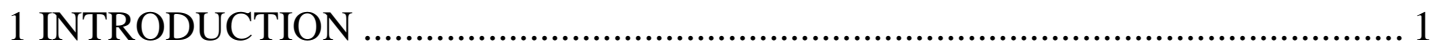

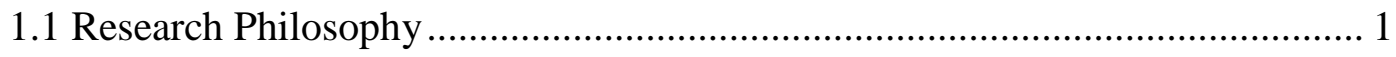

1.2 Statement of the Problem ....................................................................... 2

1.3 Purpose, Significance and Contribution of the Study …............................... 5

1.4 Research Aims and Objectives ............................................................ 7

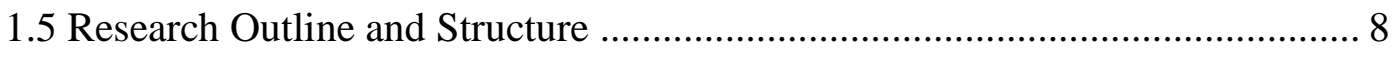

2 LITERATURE REVIEW AND THEORETICAL BACKGROUND .................... 10

2.1 The Theoretical Foundation of HPWS........................................................ 10

2.1.1 Universalistic Perspective ................................................................. 10

2.1.2 Contingency Perspective ............................................................... 13

2.2 High-Performance Work Systems and the Service Sector ........................... 14

2.3.1 High Performance Work Practices in Iran and Islamic Point of View ......... 15

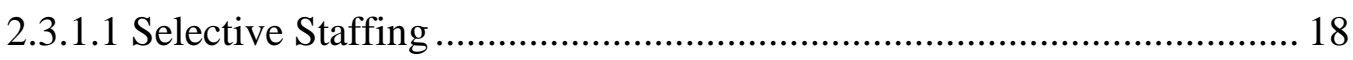

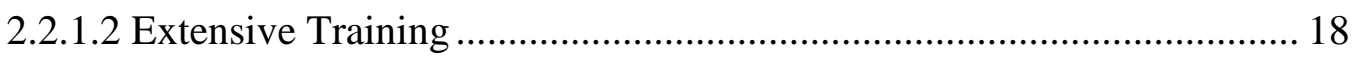

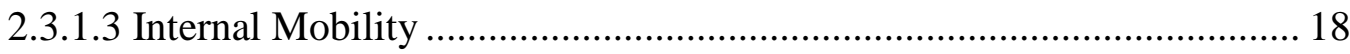

2.3.1.4 Employment Job Security …........................................................... 19

2.3.1.5 Clear Job Description and Performance Appraisal ............................. 19

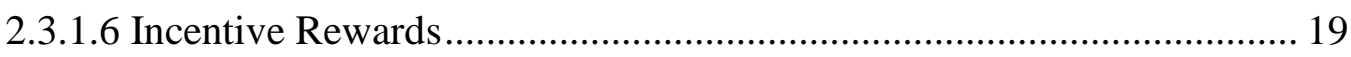


2.3.1.7 Participation

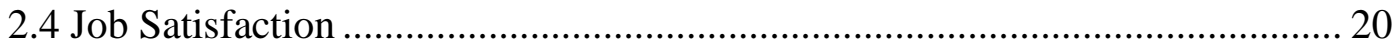

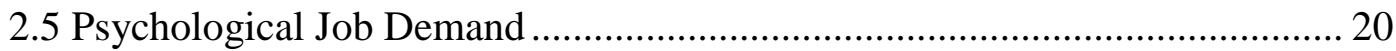

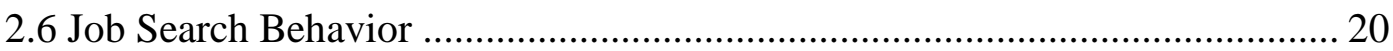

3 THEORETICAL MODEL AND HYPOTHESES ............................................... 22

3.1 High-Performance Work Systems and Job Satisfaction ............................... 22

3.2 High-Performance Work Systems and Job Demands ................................... 23

3.3 Job Satisfaction and Job Search Behavior ..................................................... 25

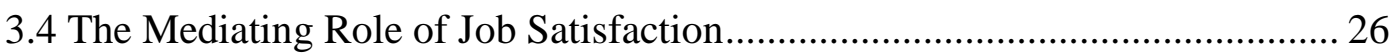

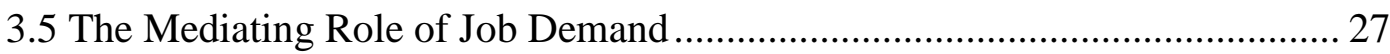

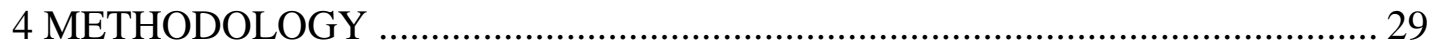

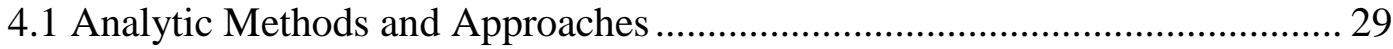

4.2 Choosing the Sample from Population .......................................................... 31

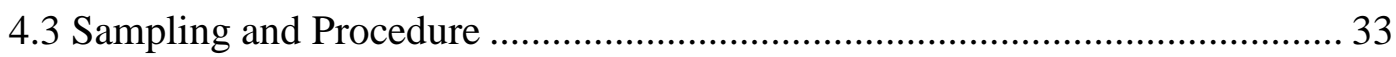

4.4 Common Method Biases............................................................................ 35

4.5 Common Method Biases Remedies ............................................................ 36

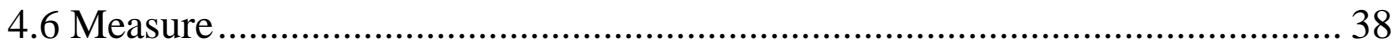

4.6.1 High-Performance Work Systems (HPWS).......................................... 38

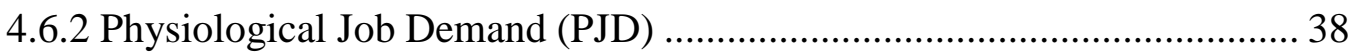

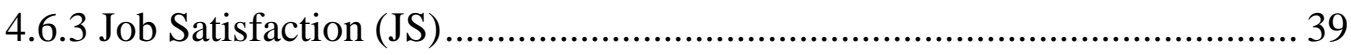

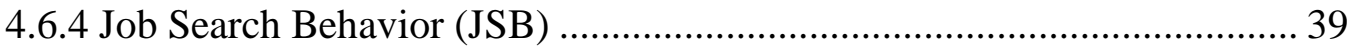

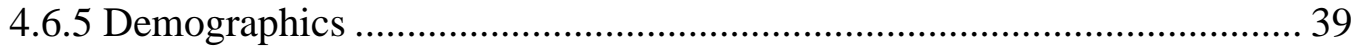

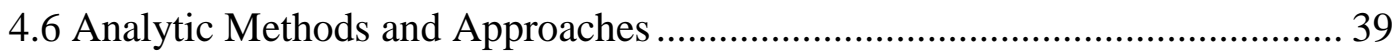

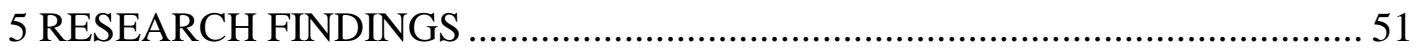

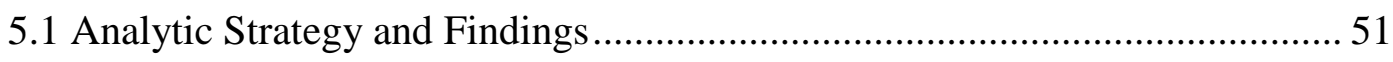




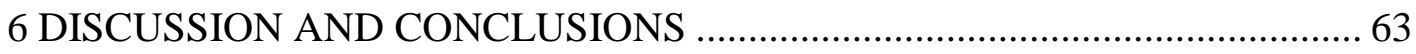

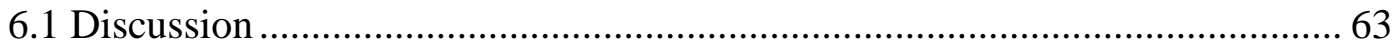

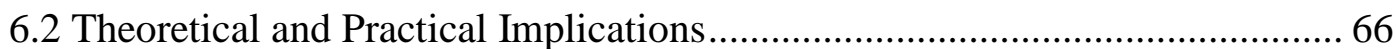

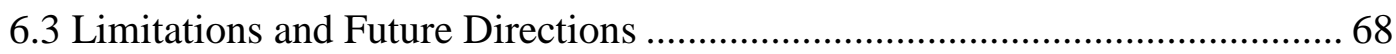

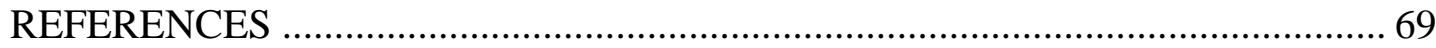

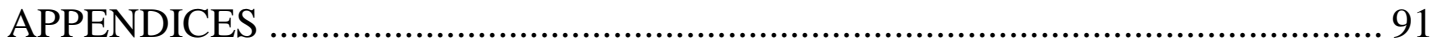

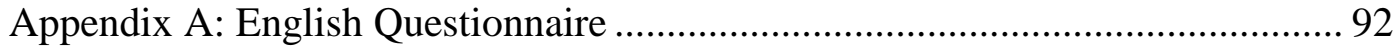

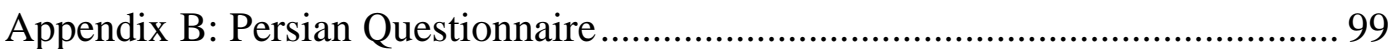




\section{LIST OF TABLES}

Table 1: Skewness and Kurtosis ...................................................................... 40

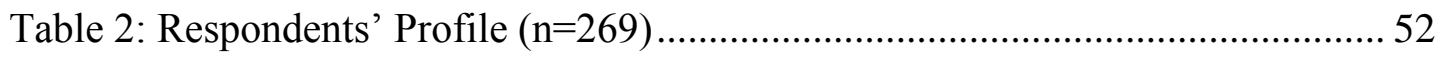

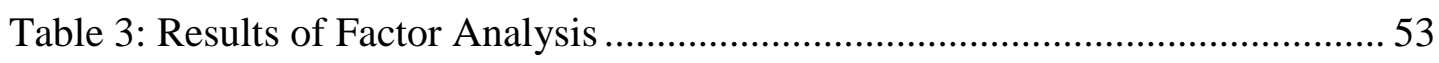

Table 4: Means, Standard Deviations (SD), and Correlations of Study Variables.... 56

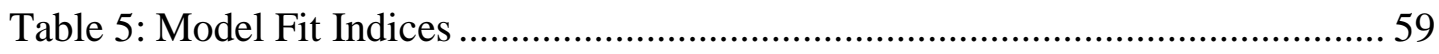

Table 6: Maximum Likelihood Estimates For The Research Model........................ 61

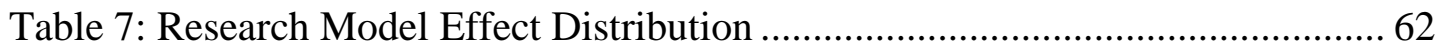




\section{LIST OF FIGURES}

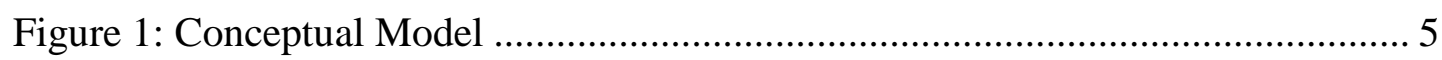

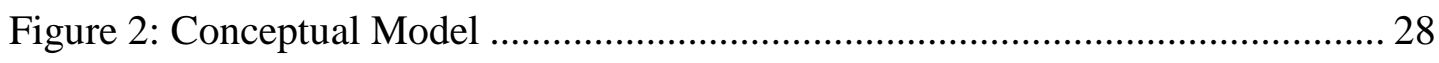

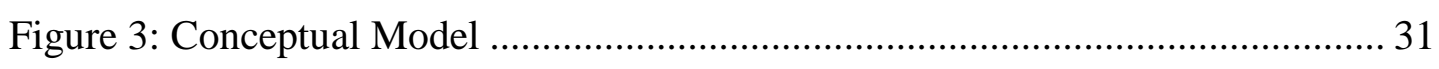

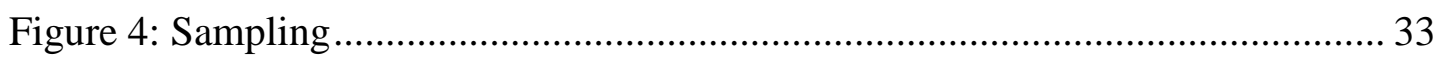

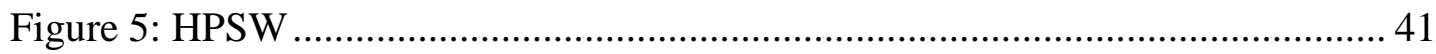

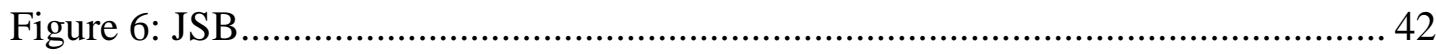

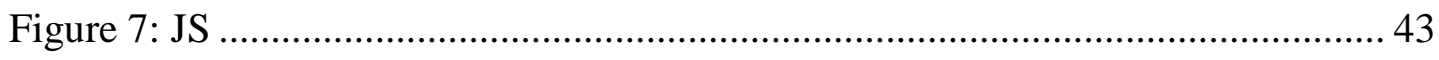

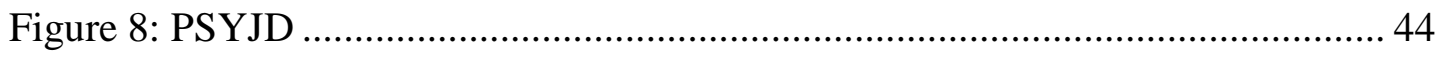

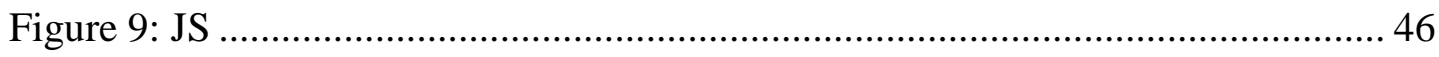

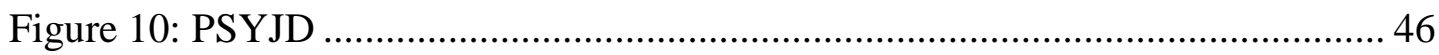

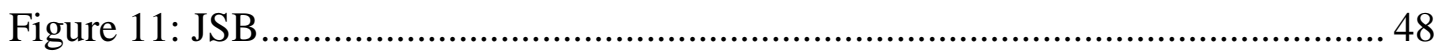




\section{Chapter 1}

\section{INTRODUCTION}

\subsection{Research Philosophy}

A review of the emergence of Human Resource Management in different countries demonstrates that HRM is perceived divergently by organizations in the developed and the developing countries. While developed countries view their human resource as a valuable asset and precious source of competitive advantage and also HRM as vital strategic function; in contrast, developing countries view the HRM still as administration basic personnel tasks and have not yet made the link between different HRM functions and improved individual performance. Hence, development and perception of HRM strategies and practices in each country is unique; it can be shaped by various factors base on national, environmental, cultural and morale differences. Organizations are urged to find the right balance of human resource management practices to deal with all those differences, develop their human capital; manage employees' psychological resources, attitude and behaviors and lastly improve organizational performance.

High-performance HR practices (high commitment or high involvement HR practices) are the principal means which help firms to influence and shape knowledge, skills and the behaviors of their employees to accomplish organizational aims and goals (Chiang et al., 2014) . 
High-Performance work systems (HPWS) are generally referred as a system of interrelated HR practices seeking to select, manage and retain the top human capital (Lepak et al., 2006). HPWS comprise training, participation, incentivized compensation, selective staffing and flexibility (Pfeffer, 1998) and are believed to be linked to greater job satisfaction, lower turnover, higher productivity and improved decision making (Combs et al., 2006). Bowen and Ostroff, in 2004 developed a framework for having a better understanding of HRM practices as a system which can support firm performance by enhancing the motivation among the employees to adopt preferred attitudes and behaviors with the intention of strategic goals achievement.

\subsection{Statement of the Problem}

Through the review of the literature, it is found that most of the studies about HPWS are focused on positive impacts of HR practices in organizations, and there are relatively few studies on their negative influence (e.g. Page et al., 2018). The research on the positive outcome variables of HPWS is very extensive; such as lower turnover (Batt, 2002) improved service performance and more commitment (Chuang \& Liao, 2010). HR practices, as a collection of management practices, are extensively believed to help communicate organizational values (Mostafa, 2017). In other study by Boselie et al., (2003), Good HR practices are conceptualized to be "signals" from managers to employees; that communicate the organization's policies, expectations and intentions. For instance, training signals to employees that the company is willing to invest in and promote its employees; promotion opportunities signal that company observes and values its individual workers' contributions (Kundu \& Gahlawat, 2016). Thus, the conventional viewpoints state that HPWS 
benefit and improve employee well-being, which in turn leads in greater organizational performance.

On the other side, some scholars skeptically oppose this view and declare that HPWS always do not have the expected positive effect on employee well-being. The relationship between HPWS and employee performance may not be a linear relationship; there seems to be other variables in between, some mediating variables or adjusting variables that can make influence, and they can lead negative consequences such as strain and higher workloads (e.g., Van De Voorde et al., 2012), work intensification, work demands and more stress (García-chas \& Neira-fontela, 2016). Therefore, Critical and condemnatory views argue that HPWS necessarily are not "good" for all employees all the time, because ultimately, HPWPs are kind of management tools designed to control employees and the primary goal is accomplishing better outcomes and results for the company' benefit (Greenwood, 2002; Luther, 2000). Henceforth, the influence mechanism of HPWS's work performance on employees is still a black box (Yi et al., 2018). So, there is dearth of studies for more investigation on not only the positive but also the possible negative effects of HPWS in the organizations, mainly at the individual level through understanding the process where HPWS affects individual attitudes and behaviors (e.g. Harley et al., 2010; Van De Voorde \& Beijer, 2014). Moreover, in spite of the growing body of research on high performance work systems (HPWS), and overflow studying on positive Impacts confirm that the high-performance work system can bring about a series of positive changes for the organization; there is lack of evidence on their implementation of HPWS and the negative influence on employee outcomes (Peccei et al., 2013) in developing countries (Ayentimi et al., 2018) and specifically in service sectors (Harley et al., 2007). 
In many developing countries such as Iran, despite young, well-educated human capital, lack of appropriate HRM systems has negative effects on, not only the human resource but also organizational performance. Many talented and smart workforces are suffering from inefficient HRM systems. Inappropriate HRM practices can leave them discouraged and hopeless. So, for many of them, financial or economic motives are the main reasons to keep them in work, not their interest or desire. This will have huge cost and negative impact for organizations.

Although, Iranian private sectors are seeking and welcoming Modern Western HRM practices, but the adoption and adjustment of these practices is not quite easy and applicable due to different factors. For instance, cultural and national factors, religious beliefs or perspectives. So, for applying and having an efficient HRM systems in developing countries such as Iran, many hidden features must be considered.

However, Iran was successful in expanding education but still has many difficulties in translating this rising educated human resource into a highly productive skilled work force. The consensus in all the planning efforts is that there is still a need to capitalize on Iran's economic, social and human resource strengths. Consequently, the emphasis should be on management and development of the human resources. This requires more effective structures in organizations, better use of human capital and diminishing brain drain which are only possible with effective HRM policies and practices (Namazie \& Frame, 2007). Prior findings of Namazie (2000, 2006) suggested that, developing economies such as Iran, view HRM practices as mere administrative processes e.g. basic personnel tasks, ranging from controlling and administering rules for payroll management, not as a strategic function meant to gain 
competitive advantage. Hence, there is a need to explore to what extent the practices of HRM used as a competitive advantage can influence employee's attitudes and behaviors in Iranian context.

\subsection{Purpose, Significance and Contribution of the Study}

Based on the aforementioned research background, this study primarily focuses on the impact mechanism of HPWS on individual attitudinal and behavioral performance in developing country, Iran.

The major purpose of this research is to further our understanding of the relationship between HRM practices and employees negative behavior (JSB). Specifically, I considered the role of Psychological Job Demand and Job Satisfaction.

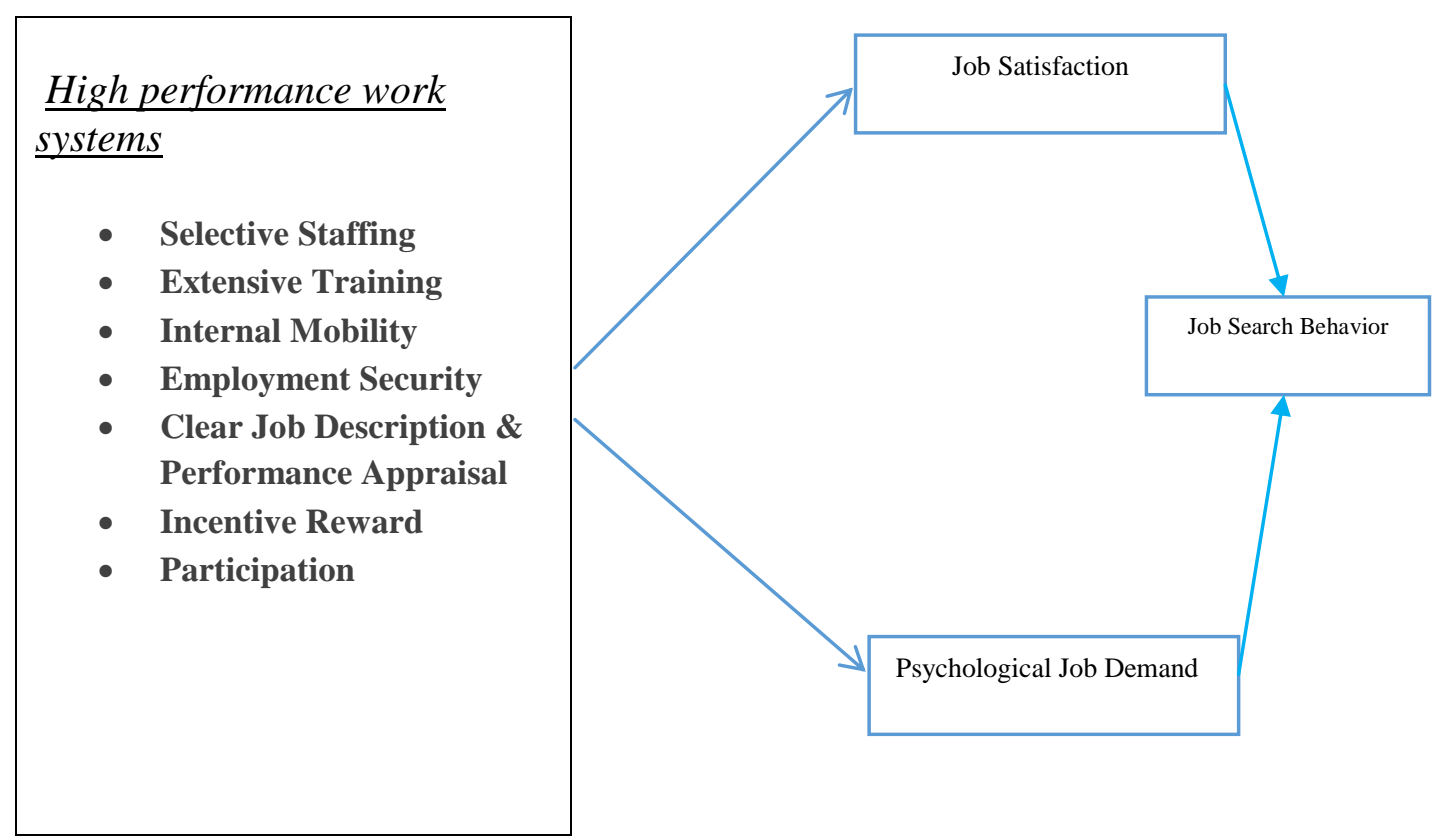

Figure 1: Conceptual Model 
In term of theoretical point of view, this study can enrich HPWS research on the mechanism of employees' performance; it can enrich the research of Conservative Resource Theory (COR) and Psychological Job Demand, and enrich the research of application of HPWS in developing country. Practically, the intermediary role of Job Satisfaction can be useful for organization practitioners to figure out the relationship between Job Satisfaction and employees' negative behavior such as Job Search Behavior.

The significant and contributions of current thesis can be divided into three aspects: First of all, this study can help managers to value HPWS, to design more adaptable and practical human resource practices compositions by considering the different characteristics of each organization based on employees' perspective, culture, religion and organizational resources. How managers can organize HPWS compositions to support the employees' need.

Secondly, according COR theory, managers by providing valuable resources can inspire employees; and make them more resistance in face of intensive job demand and can help them to improve their performance in practical works and decrease negative Job Search Behavior. The current study extends the existing literature by studying Job Search Behavior in a sample of employed individuals in service sector of developing country.

Additionally by recognizing the influence of job satisfaction on relationship between HPWS and employees behaviors can guide managers and policy makers to improve organization's performance, therefore, it can create more benefit for organization and keep an invincible position in market competition. 


\subsection{Research Aims and Objectives}

In line with prior research recommendations, the current study aims to investigate the effects of HR practices on work-attitudes such as Job Satisfaction (JSAT), Physiological Job Demand (PJD) and work-related behaviors of employees such as Job Search Behavior (JSB). PJD such as emotional demands, high work pressure, and role ambiguity may cause exhaustion, sleeping problems, and impaired health among employees (e.g., Halbesleben \& Buckley, 2004). Based on a study by Alarcon (2011), higher demands, limited resources, and reduced adaptive organizational attitudes are correlated with withdrawal behaviors. HPWS was found to be associated with turnover (Jiang et al., 2012), similarly, JSAT and PJD were found to be related to turnover (Alarcon, 2011). Hooft and colleagues (2004) emphasized that the initial step for turnover is a behavior of looking for new employment also known as Job Search Behavior. JSB is defined as "behavior through which effort and time are expended to acquire information about labor market alternatives and to generate employment opportunities" (Boswell et al., 2012, p. 129). JSB is an activity related to identifying job opportunities and collecting information about job alternatives that one selects (Barber et al., 1994).

A recent stream of empirical research has shown evidence that employees' evaluations of HR activities are indeed important to achieve insight in relationships between endorsed HRM and employee outcomes (e.g. Den Hartog et al., 2013). Hence, it is necessary to explore employees' perception of HPWS in addition to management to understand the psychological process through which HPWS influences individual employees' human capital, motivation, and behaviors (Lepak et al., 2006). The present study seeks to address this research gap by examining both 
positive and negative impacts of HPWS in the work place. Accordingly, the main aims and objectives of this study are to answer following questions:

- Does employee's perception of HPWS lead to employee's negative behavior such Job Search Behavior through higher Job Demands?

- How Job Satisfaction and valuable resources in organizations can diminish or buffer negative effect of HPWS and Psychological Job demand?

- In a global setting, a main question is whether HRM practices that work in one country work the same in other countries. How companies can adjust with the potential culture clash between the HRM values of the West and those of developing (Muslim) countries. This research is trying to investigate what the potential outcomes and influence of these very significant differences might be on application and consequence of HPWS in developing countries such as Iran. Firms in developing countries ought to use their advantages in leveraging HPWS to improve employee's performance.

\subsection{Research Outline and Structure}

This research is comprised of six chapters and its structure is as follows:

Chapter one consists of introductory part of the study. It presents the research philosophy and the background of the study. Statement of the problem, purpose, significance and main contributions of the study. Research aims and objectives.

Chapter two focus on the relevant literature review, theoretical background of research variables, what has been studied and found by previous scholars and practitioners regarding proposed variables. 
Chapter three presents theoretical model and hypothesis. It depicts theoretical frameworks and hypothetical interaction of proposed relationships and variables and provide theoretical evidence to explain and support the research hypotheses.

Chapter four is about the methodological approach and conceptual model employed in current study. This section provides information about how the research was conducted. Brief explanation about sampling and procedures. The reasons to choose the current sampling methods in our study. What is CMV and how we deal with it. The variables measurements and scales, and the applied analytics methods.

Chapter five presents the data analysis and empirical results and findings of the current study.

In the last chapter, summary and discussion about findings will be indicated. It also mentions the theoretical contributions and managerial implications and some limitations of study. Lastly some recommendations for future studies are suggesting. 


\section{Chapter 2}

\section{LITERATURE REVIEW AND THEORETICAL BACKGROUND}

The aim of this chapter is to mention the main perspective regard to High Performance Work Practices from early stage of study on HRM. Existing literature of the given HPWS in service sector will be discussed and thereafter, HPWS in Iran and Islamic point of view will be examined, additionally in detail each of the high performance management practices in Iranian context will be mentioned: Selective Staffing, Extensive Training, Internal Mobility, Employment Security, Clear Job Description and Performance Appraisal, Incentive Rewards and Participation. Other proposed variables in the current study will be explained: Job Satisfaction, Psychological Job Demand and Job Search Behavior accordingly.

\subsection{The Theoretical Foundation of HPWS}

Since 1990s various theories and approaches have been evolved in regards to the effect of HRM practices on competitive advantages and improved performance in organizations. Two main approaches that many researches have been based upon are "universalistic" or best practice approach and "contingency" approach.

\subsubsection{Universalistic Perspective}

In late 1990s, on the early HRM studies, scholars have lunched some particular set of best HRM practices for firms to manage their employees regardless the industries or what strategies practices firms applied (Pfeffer, 1998). In fact, regardless of the 
context, it was assumed that any organization can improve its performance if adopts the "best practice".

Pfeffer in 1998 outlined list of seven best HRM dimensions and declared all these HR practices are crucial for any organizations which peruse the improvement of their performance. These practices consist of selective hiring, participating in decisionmaking, and training, high compensation, information sharing, self-managed team and reduced status distinction. Huselied (1995) had similar list of HR practices but added selection ration, promotion and average training hours. Later on, Delery and Doty in (1996) applied universalistic perspective "best practices" and examined the linear relationship between those practices and financial performance index. Osteman in 1994 studied the "innovation work practices" such as problem solving groups, quality management, job rotation and self-directed team.

This universalistic approach has been advanced by the work of Appelbaum et al,. (2000) and Purcell and Hutchinson (2007) to a well-known model of AMO (abilitymotivation-opportunity). HPWS are schemed to improve the knowledge, skills and abilities (KSA) of workforces and is designed to motivate employees to invest additional effort, time, and discretionary. For example, employees' ability can be enhanced by job design, compensation and personal development and training. Employees' motivation can be improved by incentive payment, reward system, participation in decision making, flexible work schedules, authority on the job and opportunity to participate practices (Saridakis and Cooper, 2017). 
Later on many empirical studies results, supported the idea of universalistic perspective to extract certain HR practices. In example, Wu and Chaturedi (2009); examined the significant positive relationship between HRM practices such as selectivity, performance-related pay formal appraisals, internal career opportunities, empowerment, and comprehensive training and organizational productivity; or in another study, Sheehen (2014) found HR practices such as recruitment and selection, performance-based pay, development, employee participation, performance appraisal training, significantly enhanced the profitability innovation, and decrease employees turnover.

To sum up, the main idea of "universalistic perspective" is that every firm should adopt these "best" practices to improve their performance and outcome (Colbert 2004). This perspective has gradually evolved to form the broad term of "HPWPs". Since pioneer statistically analyzed studies on HRM and performance was established in the 1990s (Huselid, 1995; Macduffie, 1995), abundance of HRM scholars has tried to illustrate that a set of or bundle of HR practices or High Performance Work Practices in strategic HRM can improve firm performance. HPWPs are conceptualized as a "set of distinct but interrelated HRM practices and policy, rather than sole HRM practices" with purpose to "select, develop, retain, and motive" employees to acquire firm goals (Guthrie et al., 2004).

Albeit, extensive published studies are indicating the positive association between HRM and firm performance, still there is difficulty to understand to illustrate the casual link (e.g. George Saridakis, 2017). There are many arguments about "universalistic approach" such as HRM best practices can be imitated by many rival 
organizations, or this approach does not consider the contextual environment and rarely considers the interaction between HRM and other organizational variables. Unsuccessful attempts of many organizations to apply the "best-practice" approach in different context outside of US and UK are also practical evidence of those objections.(Boselie et al., 2005; Khatri, 2000) Therefore, alternative approach have been introduced.

\subsubsection{Contingency Perspective}

More sophisticated perspective of HPWS is "contingency perspective", also widely known as "the configurational perspective" of HRM. This approach is focusing on different factors and conditions base on the type of employee, internal and external situations of a firm, the impact of culture, managerial approach, and local context and organizational setting (e.g. size). In other words, this approach is declaring that relationship between HPWS and performance is not straight linear, many mediation or moderation variables of contextual setting with particular characteristics can influence performance outcome (Delery and Doty, 1996). So, there is no specific universal best practice applicable for all organizations. Consequently, each HPWS practices must be contingent and fit base on organizations actual situation, such as national cultural difference (Rabl, 2014), industrial environment and context (chi, 2011).

Study by Combs et al.,(2006) revealed that, HPWS are more effective in manufacturing sector rather than in service sector. Manufacturing companies rely more on organization specific competencies and adoption to technological changes (evans, 2005), as the operation in manufactures are more complex in comparison to the service sectors. 
In service companies, it is really crucial to motivate the service employees to interact with customers elegantly. Employees need certain discretion to be able to satisfy customer's different needs (Bown, 2002); therefore, contingency effect of different industrial context is inevitable and differentiated HPWS should be applied in different sectors. HPWS can positively influence performance in many cases, but there is possibility that effect of HPWS can be zero or negative in different context, due to various mediating or moderating effects such as environmental factors, national culture of host (adopted) country (Rabl, 2014); consequently, firms must be cautious to adopt and adjust HPWS to possible contingency features, and apply favorable interactions with all these different factors for desired outcomes.

\subsection{High-Performance Work Systems and the Service Sector}

According to management theory, one of the main strategies for service organizations is to focus on providing high quality service to enhance customer satisfaction (Porter, 1980). If organizations desire high-quality service from frontline employees, they need to design a work system that ensures employees have the proper knowledge, skills, motivation and abilities to meet customer demands. Service employees are closer to customers, thus, the effects of HPWPs on employee behavior can directly influence quality (Batt, 2002). Finally, since organizations are under constant pressure to improve the efficiency of their services, understanding the facets that are related to attitudes and behaviors is vital, as these outcomes are considered crucial to improving organizational delivery of services (Taylor, 2013).

Based on the framework of HPWS defined by Sun et al. (2007), the current study evaluates how HPWS effectively relates to employees' work attitudes and behaviors 
in banking service sector in Iran as a system of human resource practices designed to boost employees' motivation, competencies and performance. This study develops and tests hypotheses regarding the withdrawal behaviors of individuals as a negative phenomenon in banks alongside the generally expected positive influence of HRM practices on employees' behavior.

\subsubsection{High Performance Work Practices in Iran and Islamic Point of View}

The existing literature on HR practices in general rely on data from companies that operate in the Western world. Posthuma et al. (2013) have mentioned that the development of HPWS has received very little attention in different cultural contexts. However, cultural differences can alter the nature of HPWS effects on employee's work behaviors and attitudes (Robert et al., 2000) and thus the resulting competitive advantages would be different in different cultural contexts (Kundu \& Gahlawat, 2016). Policy makers and HR specialists in Islamic countries are struggling to apply and fit in the imported approaches from the Western cultures (Karim et al., 2017), failures in duplicating western HR practices to get desired results in other cultures have triggered scholars (Punnett, 2015) to advocate considering local culture and value sets in designing HR practices. There is a question whether Western HR practices are effective in Iran as an Islamic country with composite cultural characteristics such as high collectivism, high preferences for avoiding uncertainty, hierarchical structured and restrained society. Islamic countries are dealing with the problem of religious duties and norms in the face of Western management ideas and solutions (Ali, 2010). Recently, there has been increasing interest focused on Islamic Work Ethics and its impact on organizations in terms of employee satisfaction and loyalty (Ali et al., 2007), Islamic finance (Cheng \& Liu, 2009), and Islamic leadership (Kalmbach, 2015). However, there is still lack of studies in Islamic 
management and HRM in Islamic contexts (Khan et al., 2015; Habib R. \& Malik, 2016). Human resource management needs to be studied in Islamic societies since many assumptions about attitudes, behaviors and achievement will differ from secular societies (Ramadani et al., 2017).

Human resource practices are affected by religious issues in terms of how to behave with employees properly, determining what is right and wrong, equal employment opportunities, job security, participative in decision making, punishment and rewards, work and spirituality, employee relations and other areas that we may directly and indirectly relate to human resource management practices (Fesharaki, F., \& Sehhat, S. 2018; Paloutzian et al., 2014).

Some aspects of HRM in the Islamic context may be very similar to general HRM practices. For example, Islam calls to justice in all aspects of private and social lives (Askari, 2014), and that workforce should be treated humanely to increase satisfaction and commitment. In recruitment and selection, the Islamic standards for selection into the vacant position requires that ability and merit are considered (Ahmad, 1995). However, there are verses in Quran that also emphasize the importance of trustworthiness as key criteria to look for in potential job applicants.

One of the distinctive characteristics of the Islamic concept of HRM is that it needs to cover all aspects of human life and is not only limited to the material exchange in the working relationship, but deals with social and spiritual aspects of life. Although some similarities can be found in Islamic Work Ethics and other religious and secular value systems, we also see some very unique beliefs and teachings that would be important for developing HRM policies in the Islamic context. One such belief is that 
work is considered as worship and the perfecting of work is seen as a religious duty (Ali, 2009).

Knowledge and increasing knowledge is a very important responsibility for the individuals in Islam and thus training and development as a way to transfer knowledge has to receive close attention in human resource management in organization (Fesharaki, F., \& Sehhat, S., 2018).Together with the concept of fairness, Islam provides a responsibility to the employer that employees should receive sufficient and reasonable salary based on their contributions and the difficulty of profession (Quran - Al-Qasa:27-28).

According Holy Quran all behaviors will be recorded and evaluated and anyone will face the consequences of their behaviors and actions (Quran - Al-Muddathir, p.38). Therefore, assessing the performance of members or performance appraisal should be seen as one of the most important tasks of human resource managements and can provide valuable feedback to employees to modify and correct their activities. Also, based on Holy Quran people will face rewards and punishment in this world and hereafter.

Consequently, employee's perception of human resource management practices and the effects in Islamic countries such as Iran will differ from the Western context. Choosing Iran has considerable implications from both managerial and theoretical perspectives. Iran, a country with ancient cultural heritage located in a strategic region has tremendous natural resources that require investment. It also has a relatively large young population i.e. $82,147,166$ with the median age of 30.1 years 
(worldometers.info, 2018). In previous decades, the country's economy experienced challenges caused by the Islamic Revolution, war and reconstruction (Behdad, 2000).

Information below is provided to mention the perception and trends regarding HPWS subscales in Iran.

\subsubsection{Selective Staffing}

Most Iranian companies either public and private sectors do not bind themselves to use formal recruitment or selection structure. Iranian companies mostly consider candidate's years of experience, qualifications and connections. One the main factor in Iranian firms for recruitment is nepotism or hire someone who is introduces by someone currently is working in the company. This is because of Iranian culture is very family oriented and relationship-oriented. They believe that known person is more loyal and committed. (Namazie et al., 2006)

\subsubsection{Extensive Training}

Among Iranian organizations, formal education is seeing as preferable form of training and those leading to academic qualifications, such as MBAs. However, they believe the importance of training, but there is less structural and continues training programs. Main form of training in Iran is lecture style and didactic.

\subsubsection{Internal Mobility}

Due to Iranian cultural factor such as relationship-oriented, promoting and recruiting the current workforce (internal), is a common practice. But internal mobility in Iranian firms requires a transparence, clear, strong culture to encourage all employments to explore internal mobility and develop their skills for the next role. 


\subsubsection{Employment Job Security}

Recently, due to U.S sanctions and severe economic and financial crisis on different sectors in Iran, many employees who are currently employed, strongly feel the threat to their job security in current market.

\subsubsection{Clear Job Description and Performance Appraisal}

Alongside international companies which is usually adopting a structural approach and using a clearly defined job description, Iranian organizations -both private and public sectors- also have a similar structure; but not in very detailed and formalized structure. In Iranian companies, Performance appraisal has not had a very good reputation in Iranian companies due to distrust of employees to their line managers and existence of favoritism in such appraisals. Additionally in Iranian organizations, performance appraisal is mostly used as a tool to assess people's actions in the past, not necessarily to develop their employee's skills and ability as capital resource for the company in the future. (Namazie et al., 2006)

\subsubsection{Incentive Rewards}

In Iranian firms, compensation and rewards system is somehow complex and not very transparent. Most of staffs are not very clear about different layers of rewards and benefits. The public sector mainly applies a lower base salary and lots of benefits regarding the family of employees. For instance, different club membership, short term and vocational house, loan for family and marriage. The private sector mostly conforms to basic labor law practices and applies a bit higher base salary for incentive compensations.

\subsubsection{Participation}

In societies such as Iran, people have the perception that their actions are restrained and controlled by strict social norms and rules. Furthermore, they accept the 
hierarchical order in the workplace and expect to receive very specific and clear instructions on what to do and they are willing to accept the benevolent autocrat. Thus, Employee participation in decision making is not very welcomed in Iranian firms.

\subsection{Job Satisfaction}

Cranny et al., (1992) have proposed Job Satisfaction is "an affective (that is, emotional) reaction to one's job, resulting from the incumbent's comparison of actual outcomes with those that are desired (expected, deserved, and so on.)"' another scholar defined job satisfaction as "pleasurable emotional state resulting from the appraisal of one's job as achieving or facilitating one's job values. Job dissatisfaction is the unpleasable emotional state resulting from the appraisal of one's job as frustrating or blocking the attainment of one's values" (Locke, 1969, p. 317). Brief (1998) states that job satisfaction "is an attitude toward one's job".

\subsection{Psychological Job Demand}

Job Demands (e.g., time pressure) are defined as "those physical, social, or organizational aspects of the job that require sustained physical and/or mental effort and are therefore associated with certain physiological and psychological costs". High Job Demands (e.g., work overload or emotional demands) may drain an employee's physical resources and mental resource, leading to the exhaustion of energy (Bakker et al., 2005).

\subsection{Job Search Behavior}

Job search or perusing of new employment and new career opportunities, among employed and unemployed people has become prevalent behavior. Some individual differences such as personality traits, self-esteem, locus of control or financial motives and macroeconomics variables like occupational or industry variables and 
also indirect effects of several variables such as organizational commitment, work valence, work overload, job security, expectancy and job satisfaction have been considered as antecedent of job search (Kanfer et al., 2001). During job search, individual generally have to engage in variety of activities and consume different resources (time, social resource and effort) for obtaining new employment. They may occupy in different actions to find a new employment. For instance, "prepared a resume" "go to a job interview" or "read the classified ads". During job search, person may feel unsecure, unsure and being easily discouraged and for current employees, it decreases their efficiency and productivity.

Despite the gradually growth in study about Job Search Behavior among scholars, investigated the predictors of Job Search Behavior in employed samples and voluntary turnover (Bretz et al., 2001) is still limited and has attracted a considerable amount of research attention towards other antecedent of Job Search Behavior. 


\section{Chapter 3}

\section{THEORETICAL MODEL AND HYPOTHESES}

The aim of this chapter is to indicate theoretical model and hypothesis. It depicts theoretical frameworks and hypothetical interaction of proposed relationships and variables and provides theoretical evidence to explain and support the research hypotheses.

\subsection{High-Performance Work Systems and Job Satisfaction}

Job Satisfaction is defined as "the assessment of one's job or work experience that leads to a positive emotional or pleasurable state" (Locke, 1976, p. 1300). Previous studies demonstrate a direct positive relationship between HPWS and Job Satisfaction since as a bundle of HR practices. HPWS engender a two-way relation between employees and the organization. When faced with organizational practices that enhance employee wellbeing, development and opportunities to utilize their skills, employees reciprocate with positive attitudes (Kooij et al., 2010).

Conservation of resource theory (COR) states that people attempt to preserve, build and maintain their valuable resources. These resources refer to personal characteristics such as resilience, objects such as equipment, energies such as money or knowledge that are necessary for survival and the means to protect or enhance these resources (Hobfoll \& Shirom, 2000). Any threat of losing, actual loss or depletion of resources are conceptualized as demands in the COR theory. The fewer resources individuals have, the more maladaptive coping will be for them. This 
maladaptive coping leads to a reduction in organizational attitudes such as job satisfaction (Alarcon, 2011) whereas job resources such as performance feedback, social support and autonomy may prompt a motivational process leading to work engagement, job-related learning and organizational commitment (Demerouti et al., 2001).

By examining the literature, several clues can be found with respect to COR theory that states HPWS would be related to job satisfaction. For instance, different kinds of resources such as social support, team working climate, training, feedback, job security and promotions influence individual attitudes such as job satisfaction. Thus, the bundle of HRM practices would be expected to affect employees' job satisfaction. Consequently, this study proposes that:

H1: HPWS will be positively related to job satisfaction.

\subsection{High-Performance Work Systems and Job Demands}

Job demands indicate those social, physical or organizational facets of the job that require psychological and physical effort which lead to certain psychological (e.g., exhaustion) and/or physiological costs (Demerouti et al., 2001). Hobfoll (2001) by using the COR theory argues that the primary human motivation is directed towards achieving and maintaining the resources if there is loss of resources, or threat of losing resource, stress will occur. Stress may arise directly from work practices or can be caused by demands of higher responsibility associated with amplified discretion, work intensification and insecurity (Ramsay et al., 2000).

According COR theory, stress can be caused directly by the demands of higher responsibility, increased discretion and work intensification (Ramsay et al., 2000). 
Although training generally leads to a positive impact on employee performance and an improvement in their skills, if the organizations only focus on very specific training that does not have observable improvement and only feels like a requirement to fulfill certain external standard (such as ISO certification requirements), inefficient of inappropriate training can also result in psychological costs among employees such as exhaustion from work overload. Organizations should implement HPWS to create a better fit between people and the task to boost the productivity and workplace performance (Budhwar \& Varma, 2011). Training should not just focus on the work alone, but also problem solving, communications, time/meeting management, and process redesign. Thus, we advocate that HPWS implementation should focus on "the way the work is done" by facilitating flexible work processes that adapt the people and the technical systems to each other.

The critical management-by-stress perspective argues that HPWS may lead to several negative consequences for employees; it might also intensify employees 'job demands and have a negative impact on their well-being (Wood \& de Menezes, 2012). For instance, HPWS may create feelings of high demand caused by increased workload, imposed strains, increased time pressure and high employee's stress (e.g., Bartram et al., 2012; Gulzar et al., 2014). Work overload is concerned with conditions in which employees believe that there are too many activities or duties demanded of them against their capabilities, the time on hand, and other restrictions (Jensen et al., 2013). Work demands that exceed worker's coping ability, is defined as job stress (Theorell et al., 1996). The focal point of this study is on bank employees' work overload, emotional and physical job demands as a result of intensifying HPWS and predictor of employees' withdrawal behaviors such as JSB. Therefore, from prior research (e.g. Chaudhuri, 2009) consistent with COR theory 
and in addition to above reasons that demonstrate a positive relation between HPWS and amplifying high demands, this study proposes the following hypothesis:

H2: HPWS is positively related to Job demands.

\subsection{Job Satisfaction and Job Search Behavior}

In the context of this study, JSB is an indicator of employee withdrawal behavior. Searching for alternatives and voluntary turnover intentions are a critical problem in many organizations and understanding the reasons is quite vital to explore possible pathways to preventing it (Hatton et al., 2001). Although, the process by which individuals investigate, detect, seek and decide between job opportunities is quite important and costly for both people looking for employment and the organizations that hire those people (Smith \& Gerhart, 1991). Majority of prior work focused on the role of people's work attitudes (e.g., organizational commitment, job satisfaction) and withdrawal cognitions (e.g., intention to quit) in turnover process rather than investigating the actual behaviors such as preparatory and active job search activities (Bretz et al., 1994).

Withdrawal behavior (e.g., JSB) is vexing and costly in the service industry because when service employees no longer identify with the organization and engage in seeking alternatives, they will provide poor customer service and will not be motivated to provide remedy when service problems occur leading to poor service recovery (Ashill et al., 2008). Thus, experts in service industry are striving to develop effective strategies for diminishing withdrawal behaviors (Liao et al., 2009). COR theory demonstrates that attitudinal variables such as job satisfaction are likely to correlate with withdrawal behavior in organizations (Hobfoll, 1989). Organizational attitudes are a function of limited resources and the demands placed 
on these resources. As resources decrease and demands increase, withdrawal behavior such as JSB and turnover intention tend to increase while job satisfaction tends to decrease (Alarcon, 2011).

Literature on job embeddedness and voluntary turnover behaviors states that one of the main channels through which job satisfaction can improve organization value is by retention of key employees (Becker \& Gerhart, 1996). This is where satisfaction shows its main role by enhancing job embeddedness (Tanova \& Holtom, 2008) in order to retain those talented employees. A negative relationship has been found between satisfaction and employee's withdrawal behavior (Harley, 2010). Therefore, job satisfaction is considered as a valuable tool for retaining the employees both in practice and literature. Inferring from the above line of reasoning, this study proposes that higher job satisfaction decelerates withdrawal behavior in an organization mainly JSB.

H3: Job satisfaction negatively relates to job search behavior of employees.

\subsection{The Mediating Role of Job Satisfaction}

HPWS has been found to be an antecedent of job satisfaction and job satisfaction serves as the channel through which HPWS enhances firm performance (Becker \& Huselid, 1998). More specifically, from the tenets of COR theory, it can be inferred that HRM practices can affect employee's attitudes via resource gain and loss. Subsequently, employees' work attitudes' variables such as job satisfaction and job stress influence employees' behavior in searching for alternatives or remaining in the

organization (Mobley et al., 1979). Based on this argument, we expect the HPWSJSB relationship to be mediated by job satisfaction. 
H4: Job Satisfaction will mediate the relationship between HPWS and Job Search Behavior.

\subsection{The Mediating Role of Job Demand}

Individuals searching for possible job opportunities in different organizations (Schwab et al., 1987), are not only those who are unemployed (Devens, 1988) but also those currently employed (Rosenfeld, 1977). Job search is the process of collecting information about potential jobs (Steffy et al., 1989) by identifying job opportunities and collecting precise information about those specific opportunities (Rees, 1966). The quest for immunity may subsume pursuing new employment opportunities (Abubakar et al., 2018). A number of studies indicated job stress leads individuals to search for alternative job opportunities (Lee \& Mitchell, 1994). Consistent with COR theory and studies on negative phenomena in organizations, JSB results from the same reasons that lead to turnover such as stress (Hom et al., 1992). Although, not all job search leads to turnover, all kinds of job search are costly for organizations (March \& Simon, 1958) since it will reduce energy, productivity and commitment to the current job (Locke, 1976). Therefore, there is essential need for organizations to examine the relationship between variables that motivate search intentions and search behaviors (Mobley, 1979).

Job demands diminish individual's resources and prolonged exposure will cause burnout manifested through emotional exhaustion, feelings of lack of personal achievement and cynicism (Hobfoll \& Freedy, 1993). Majority of jobs may incorporate role conflicts, role ambiguity and overload (Landy \& Conte, 2007). Role stressors are demands arising from multiple job requirements; long term exposure to these demands leads to withdrawal behaviors such as job search (Bakker \& 
Demerouti, 2007). Research reveals that management practices like HPWPs operate as contextual stressors that lead to an intensification of job demands (Kroon et al., 2009). Prior studies reveal a link between HPWP and withdrawal behavior such as job search and consider job strain and stress as results of increased job demands created by HPWS, this study examines the effect of bundles of HRM on JSB of employees. We propose the following hypotheses:

H5: Job demand influence job search behavior positively.

H6: Job demand will mediate the relationship between HPWS and job search behavior.

All hypotheses are summarized in the conceptual model in Figure 2.

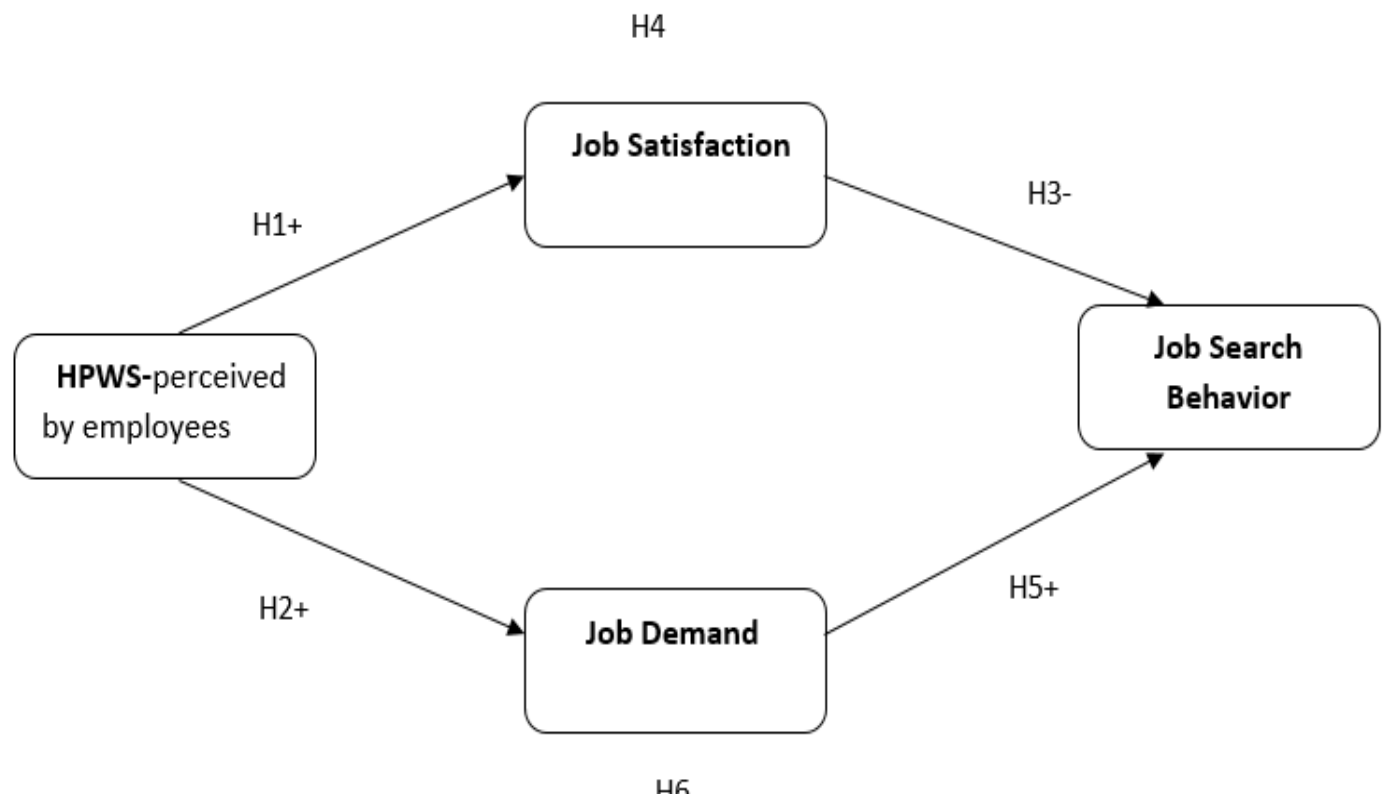

Figure 2: Conceptual Model 


\section{Chapter 4}

\section{METHODOLOGY}

\subsection{Analytic Methods and Approaches}

This chapter indicates the methodological approach and conceptual model employed in current study, presents the sampling method, procedure, sample size, location of the study, data collection measurement, procedural of data analysis and statistical results.

In Iran, banks dominate the main financial system, mainly because the stock market is not as efficient and developed as their Western and far Eastern counterparts. As the banks strive to enhance their competitive advantages, the importance and need for efficient HRM practices becomes even more pertinent in Iranian banks. Most of the banks are setting up HR departments and many apply HPWS.

Iranian government has gradually liberalized the banking sector since 2001. In 2004, there were 13,952 commercial bank branches, 53 of which were foreign branches. Specialized banks had 2,663 branches. As of 2016, the banking sector in Iran employs more than 200,000 staff in more than 23,000 branches of banks and credit institutions nationwide which imply tremendous impacts of HPWS in banking sector (Habibi \& Mohammad, 2016). Hence, the focus of this study is on the banking sector in Iran. 
After the 1979 Iranian Revolution, all banks had to operate according to Islamic laws. This makes Iran unique, since in many Islamic countries the customers may choose to use Islamic or conventional banking, but in Iran, all banks are Islamic banks. For differentiating, banks can use proper and strategic human resource practices, and develop HR systems to give them a unique advantage against the competition. Thus, human resource is one of the key business assets in Iranian banks (Estiri et al., 2011). As the banks strive to enhance their competitive advantages, the need for efficient HRM practices becomes even more pertinent in Iranian banks. In 2018, there are 20 private banks (non- Government-owned Banks) among 42 total Banks and Credit Institutions in Iran (Banks and Credit Institutions info, 2018). Banking sector in Iran employs more than 200,000 staff in more than 23,000 branches of banks and credit institutions nationwide (Habibi \& Mohammadi, 2016). Thus, the role of banking in the economy of Iran is quite prominent. Hence, we were encouraged to choose and focus on employees in the banking sector. As data gathering in Iran is challenging, especially governmental sectors which wary towards research, a great deal of time was needed to build bridge with those organizations and follow their bureaucratic procedures. Therefore, in current study we focus on private banks in Iran. All Private Banks in Iran are following the same Establishment Criteria of the non-governmental bank and Major Monetary Policies (https://www.cbi.ir/default_en.aspx). Figure1 below depicts a pictorial diagram regarding the relationship of the proposed study variables 


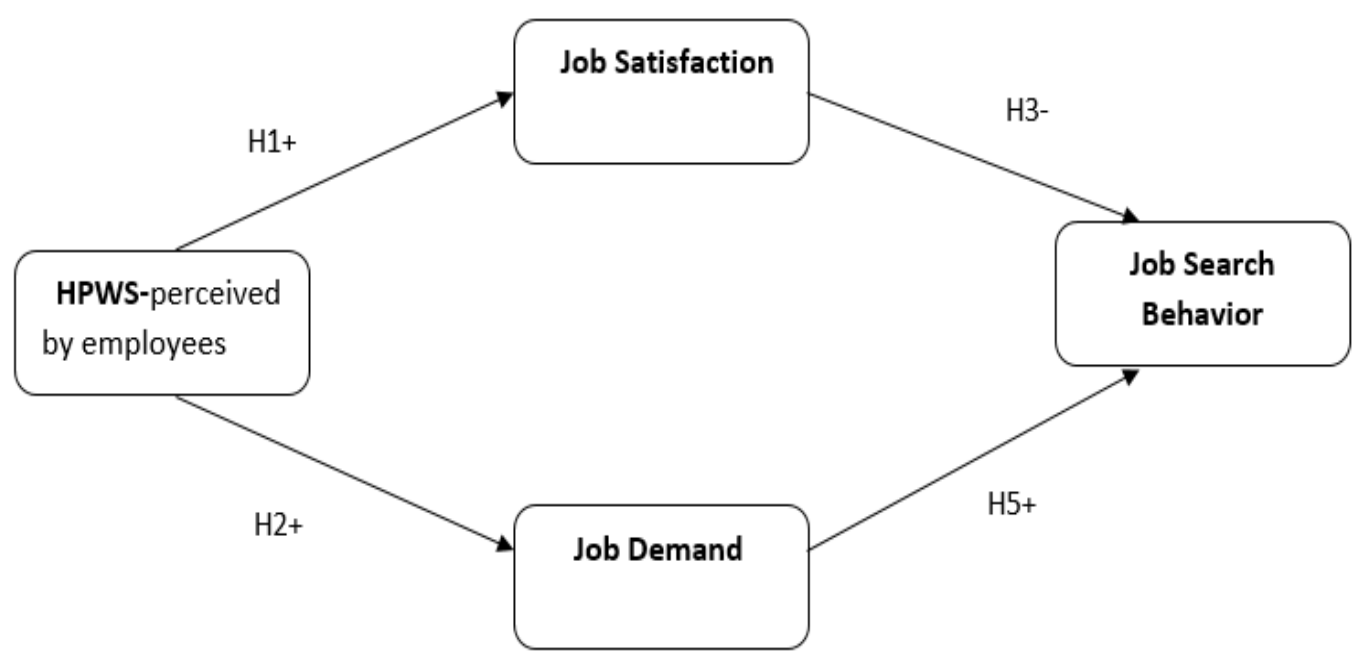

H6

Figure 3: Conceptual Model

\subsection{Choosing the Sample from Population}

Since we cannot ask all of the people to find out things about them; so we need to sample the population and ask some of them. The way in which we select sample of individuals is very critical for generalization our research findings. We examine a sample of people to answer these questions "to what extent do the results relate to all people" and also" to what extent do they only relate to our sample?"

Sampling is practical method of studying people and their thoughts, attitudes, activities, abilities and relationships in regards to business. As we do not ask everyone in chosen "population" (Greener, S, 2008) (such as members of an organization, or all $\mathrm{PhD}$ students of EMU, or all members that meet a set of specified criterion we define in regards to our research aim and objective). So, how could we make sure that our results can be representative of whole population, and our finding could be generalized to whole group? For answering that we need to know about sampling techniques. There are two major sampling techniques: probability sampling 
and non-probability sampling. With probability sampling, we can specify the probability of a participant's being included in the sample and it allows us to create a sample that is representative of the population of interest. As a very simple example, we can mention the time in high school, when teachers pulled out student's name from a hat to make their presentation in the class. There are several types of probability sampling such as simple random, stratified random, cluster and systematic.

In non-probability sampling technique, random selection is not used. In this method on the contrary of probability sampling, not all units of the populations have equal chance of participating and some of units in the population may have a higher chance of being chosen. Examples of non-probability sampling techniques are convenience sampling, snowball, purposive and Quota. (Greener, S. 2008). For instance in convenience sampling, the sample is selected for convenience or ease rather than through random sampling. This method is using mostly in pilot studies or short term projects due to insufficient time to apply a probability sample. So, the results cannot generalize to the population (Greener, S, 2008). 


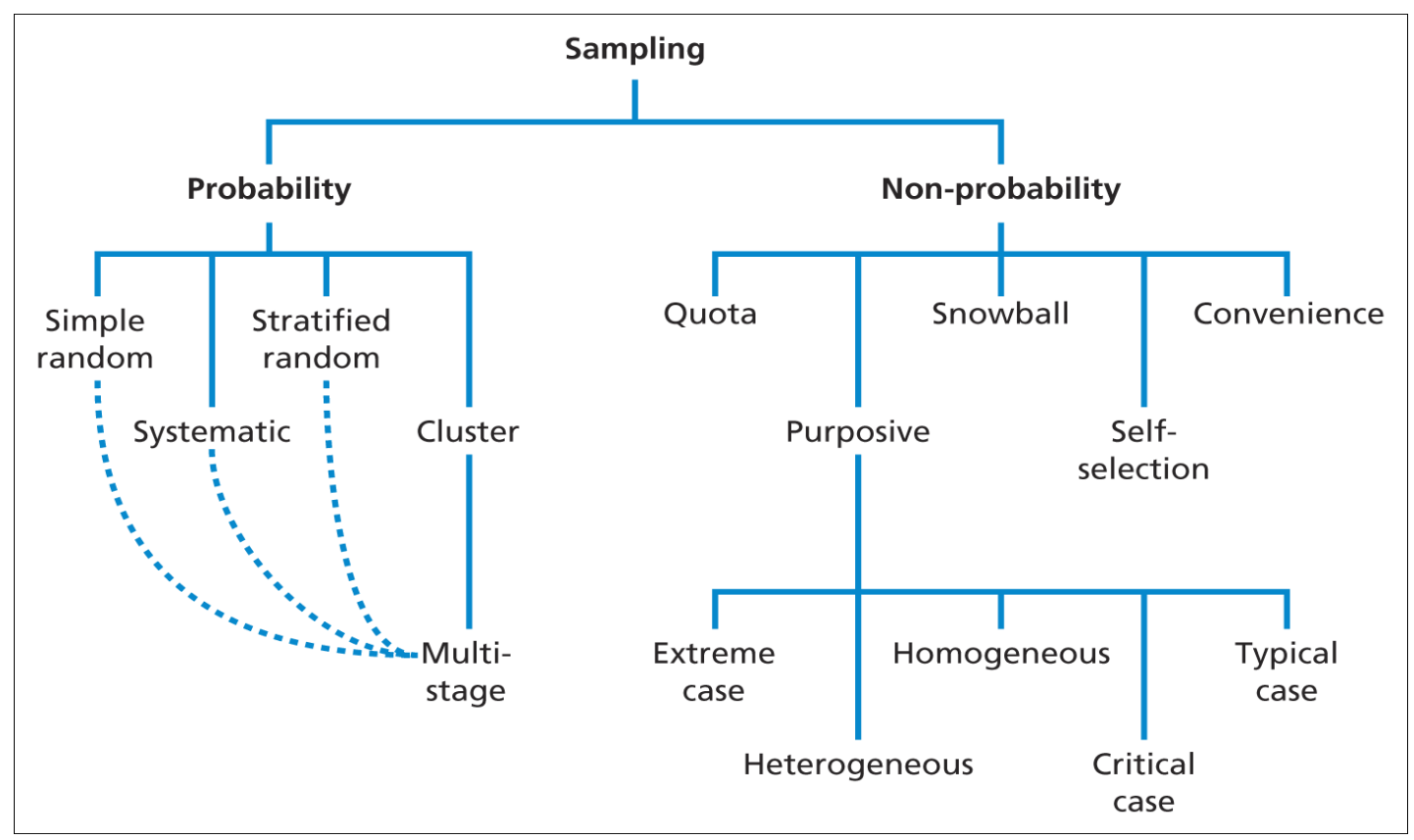

Figure 4: Sampling

Source: Saunders et al., (2009)

\subsection{Sampling and Procedure}

To achieve the current study's goal, a survey was conducted with employees of two large banks with branches located across Iran using a random sampling technique. "Random" term means that every subject has an equal chance of being chosen. The simple random sampling approach is a type of statistical sampling strategy in which a subset (study-sample) is chosen from the population of interest randomly, in a way that each member of the subset carries an equal opportunity of being chosen as a part of the sampling process. This sampling approach is representative of the target population (sample group) and leads less room for researcher bias compared to nonrandom sampling techniques. This technique is simple and easy to interpret, and it can be tedious and time consuming when we work on large sample, since this study attempted to select a sample from a larger population, and creates sample which are highly representative of the population, therefore random sampling appeared to be an appropriate and fair strategy for conducting the research. 
The questionnaire was written in English and subsequently back translated to Persian by linguistic experts. Back-translation was also performed by an independent group and both original and the back-translation was compared to ensure that the meaning remained the same. A pilot study was conducted with 25 respondents and following necessary changes were applied thereafter.

The questionnaires were distributed among employees and asked the subjects from them directly. Self-report is an appropriate method for measuring private events such as Job Satisfaction or Job Search Behavior; also it is rationale to use self-report for assess the perceived construct such as HPWS. Thus, self-report is apparently proper for our study.

Permission to conduct the survey was issued by the management of all those branches.

Questionnaires were submitted to managers by the researcher and then the manager distributed them among employees. Each participant has its unique code.

Participation was simultaneously solicited from 400 random personnel of two private large banks with branches located across Iran. Participants completed a self-reporting questionnaire assessing perceptions of high-performance work system in their respective banks at Time $I(n=326)$. After an interval of four weeks, the participants who completed the survey at Time I were asked to complete a second survey that assessed job satisfaction, physiological job demand and job search behavior. At Time II ( $\mathrm{n}=302)$, the surveys were matched using a code created by the participants and they were assured of confidentiality. 
At the end of the survey, Data for 33 participants were subsequently dropped for careless responses and incomplete data. The final sample consisted of 269 valid responses from 22 work units, with the response rate of $67.25 \%$, and 269 were used for data analysis.

\subsection{Common Method Biases}

One of disputed problem with measuring different constructs with the same method for researchers in behavioral science is "the biasing effects which measuring constructs with the same method may have on estimates of the relationships among them" or "Common Method Variance".

Common Method Variance (CMV), as one of the main measurement error occurs when covariance is attributed to the instruments, rather than the actual constructs of research' interest. It threatens the validity of the results about the observed relationships between measures of different constructs and significantly can affect the item validities and reliabilities. Putting in other words, CMV refers the variance that is attributable to the measurement method rather than to the construct. Therefore, the instruments produce a bias, rather variance which is willing to be analyzed; hence, the results are contaminated by the method biases. (Podsakoff et al., 2012).

For control and deal with different sources of method bias, there are recommended procedural and statistical remedies; procedural remedies are like "Obtain measures of predictor and criterion variables from different sources"; "Temporal, proximal, or psychological separation between predictor and criterion", "Eliminate common scale properties", "Reducing social desirability bias in item wording", "Improving scale items to eliminate ambiguity", "Balancing positive and negative items" and some 
examples of statistical remedies are "Unmeasured latent method factor technique" " Correlation-based marker variable technique" "Regression-based marker variable technique." "CFA marker technique" "Measured response style technique" "Directly measured latent method factor Technique" and "Instrumental variable technique" (Podsakoff, P. M. et al., 2012).

\subsection{Common Method Biases Remedies}

For dealing with CMV and reduces the impact of method variances, we applied some procedural remedies. A problem with self-report questionnaires and the measures is the respondents' potential susceptibility to social desirability response bias. "Social desirability" bias refers to the tendency of participates to answer the questions in ways that will view them in the best possible light. In other words, participates behave in a culturally appropriate manner that make him/ her more desirable to other people. Social desirability can affect the validity of research findings (Nederhof, A. J. 1985). Therefore, we reassured anonymity and confidentiality of questionnaires to reduce individual's perception, and make them less likely to edit their responses to be more socially desirable; this will likely reduce the potential of CMV(Podsakoff et al., 2013; Podsakoff et al., 2012).

One of the sources of error in social science which is overlooked is "nonresponse error". Nonresponse rate or number of participants that failed to respond is as serious as respondent rate to demonstrate adequate validity of data (Collier, J. E., \& Bienstock, 2007; Miller \& smith, 1983). In current study to improve the assurance of our study's result, we applied recommended methods for addressing nonresponse rate. 
One of the widely used methods is to estimate the effects of non-response in a study. We compare one of the known characteristics of the population (demographics) of respondents to the population. If this characteristic for respondents does not differ from the population, we could assume that sample is representative of the population. (Armstrong and Overton, 1977; Kish, 1965)

The effects of the non-response and missing data were evaluated by comparing the demographic characteristics of the subjects as suggested by (Armstrong \& Overton, 1977; Collier \& Bienstock, 2007). The comparison of the current research population's demographics with those of the general population; and the demographic set-up of those who participated at Time I to those at Time II showed no significant difference.

The other strategy to estimate nonresponse is "Extrapolation". Extrapolation is usually carried out over period of time. It consists of comparisons between early and late respondents in a study. If there is no difference between them, an assumption is made that the results are not contaminated by nonresponse error. (Blair, 1964; Reuss, 1943).

We compare the responses of early and late respondents on important variables of this study. For high-performance work systems mean for $($ Early $=2.93$, Late $=3.09$, $\mathrm{p}<.000$ ); physiological job demand (Early $=3.18$, Late $=3.49, \mathrm{p}<.000$ ); job satisfaction $($ Early $=3.34$, Late $=3.57, \mathrm{p}<.000)$; and job search behavior $($ Early $=$ 1.87 , Late $=1.68, \mathrm{p}<.000)$. The extrapolation of early and late respondents on both variable and also on demographic variables provides some reassurance that respondents and non-respondents do not differ on sample characteristics or in their 
specific inquiry of opinions and attitudes. In general, this increases the robustness of our data; the sample seems to be a representative of the population of interest.

Another method biases remedies we applied to reduce respondent's ability or motivation to recall information in short-term memory was the temporal separation and time delay, with four weeks interval time. Participants completed a questionnaire assessing perceptions of high-performance work systems (Predictor) in their respective banks at Time I $(n=326)$. After an interval of four weeks, the participants who completed the survey at Time I were asked to complete a second survey that assessed job satisfaction, physiological job demand and job search behavior (Criterions). At Time II $(n=302)$, the surveys were matched using a code created by the participants and they were assured of confidentiality. Additionally, proximity of the variables was applied and we placed the predictor variables and the criterion variables in separate pages.

\subsection{Measure}

\subsubsection{High-Performance Work Systems (HPWS)}

We measured HPWS with 16 highest loading items from the work of Sun et al. (2007). We instructed participants that when referring to 'HPWS' in considering how engaged in or their bank encourages employees to engage in such practices. An example item is "There are formal training programs to teach new hires the skills they need to perform their job". Responses were recorded on a 5-point scale ranging from 1 (strongly disagree) to 5 (strongly agree). In Appendix 1, scale items are provided.

\subsubsection{Physiological Job Demand (PJD)}


We measured PJD with 5 highest loading items adopted from Karasek et al. (1998). An example item is 'my job requires long periods of intense concentration on the task'. Responses were recorded on a 5-point scale ranging from 1 (strongly disagree) to 5 (strongly agree). Coefficient alpha was .76. Appendix A.

\subsubsection{Job Satisfaction (JS)}

We measured JS with 3 items adopted from Netemeyer et al. (1997). An example item is 'All things considered (i.e., pay, promotion, supervisors, co-workers, etc.), how satisfied are you with your present line of work'. Responses were recorded on a 5-point scale ranging from 1 (strongly disagree) to 5 (strongly agree). Coefficient alpha was .85. Appendix A.

\subsubsection{Job Search Behavior (JSB)}

We measured JSB with 10 highest loading items from Blau (1994). Participants were asked to indicate how much time they had spent in the last four months on several preparatory and active job search activities. An example item is 'Spoke with previous employers or business acquaintances about possible job leads'. Responses were recorded on a 5-point scale ranging from 1 (no time at all) to 5 (very much time). Coefficient alpha was .93. In Appendix A, scale items are provided. Appendix A.

\subsubsection{Demographics}

Demographic variables used in this study include age, gender, marital status, education level, and monthly income, years of job tenure. Appendix A.

\subsection{Analytic Methods and Approaches}

The present study has used a structural equation modeling with maximum-likelihood estimation utilizing IBM-SPSS AMOS v21 for data analysis and measurement 
assessments. The combination of employing SPSS and AMOS were confirmed in previous studies (e.g. Wen. et al, 2018).

The effects of the non-response and missing data were evaluated by comparing the demographic characteristics of the subjects as suggested by (Armstrong \& Overton, 1977; Collier \& Bienstock, 2007).

A preliminary analysis was conducted to assess the estimation regarding normality, linearity, and homoscedasticity of the measurement model.Table1.

According to George and Mallery (2010), asymmetry and kurtosis coefficients between -2 and +2 confirm normality of data, and our test for normality satisfies this condition. This result implies that the data set of the present research was free from skewness and kurtosis problems. Figure 5-8.

Table 1: Skewness and Kurtosis

\begin{tabular}{|l|l|r|r|r|r|}
\hline \multicolumn{2}{|c|}{ Statistics } \\
\hline \multirow{2}{*}{$\mathrm{N}$} & JSB & \multicolumn{1}{c|}{ JS } & PSYJD & \multicolumn{1}{c|}{ HPWS } \\
\cline { 2 - 6 } & Valid & 284 & 284 & 284 & 284 \\
\cline { 2 - 6 } & Missing & 0 & 0 & 0 & 0 \\
\hline Skewness & 1.139 & -.644 & -.552 & -.008 \\
\hline Std. Error of Skewness & .145 & .145 & .145 & .145 \\
\hline Kurtosis & .440 & -.229 & 1.874 & -.538 \\
\hline Std. Error of Kurtosis & .288 & .288 & .288 & .288 \\
\hline
\end{tabular}




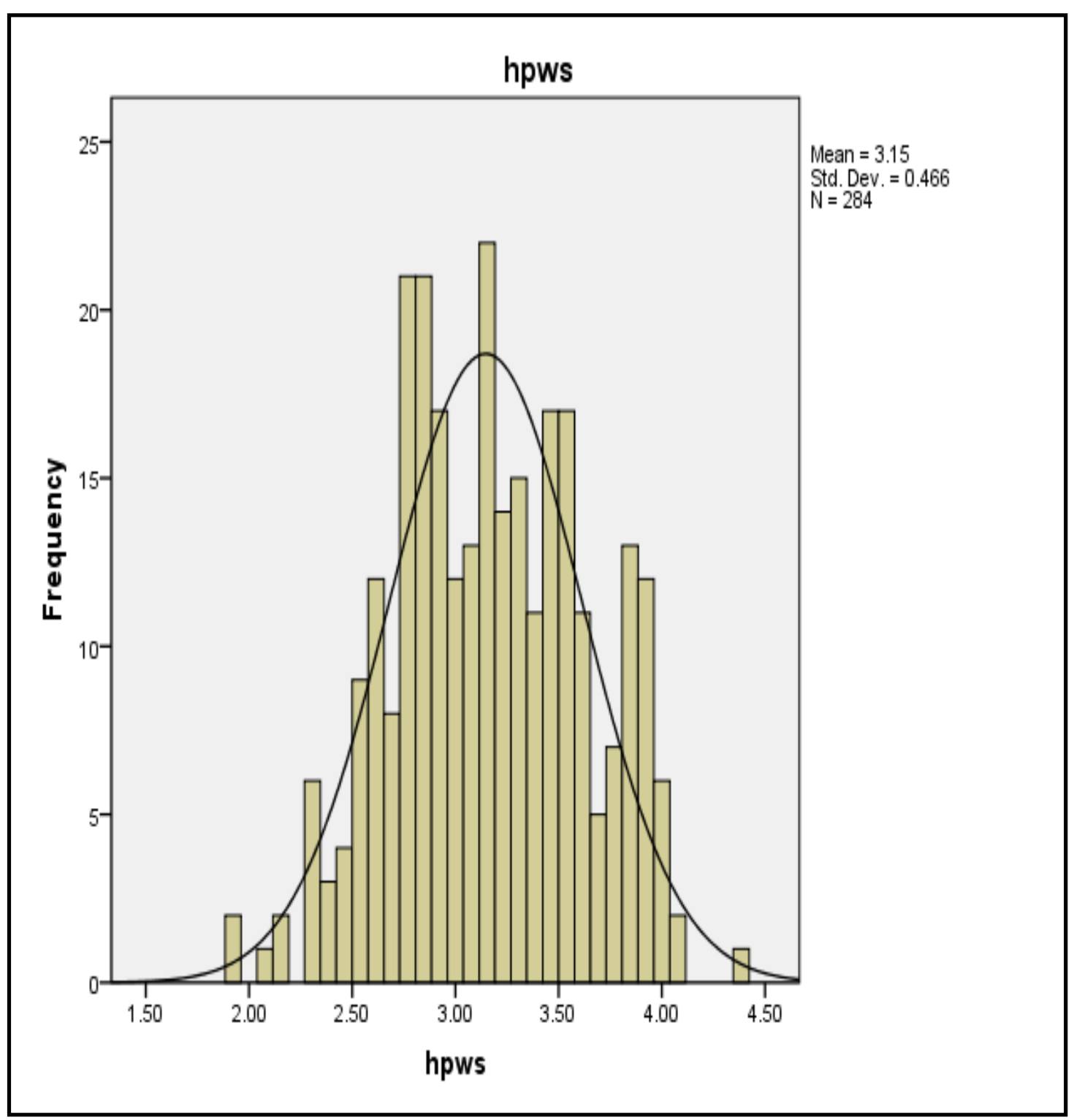

Figure 5: HPSW 


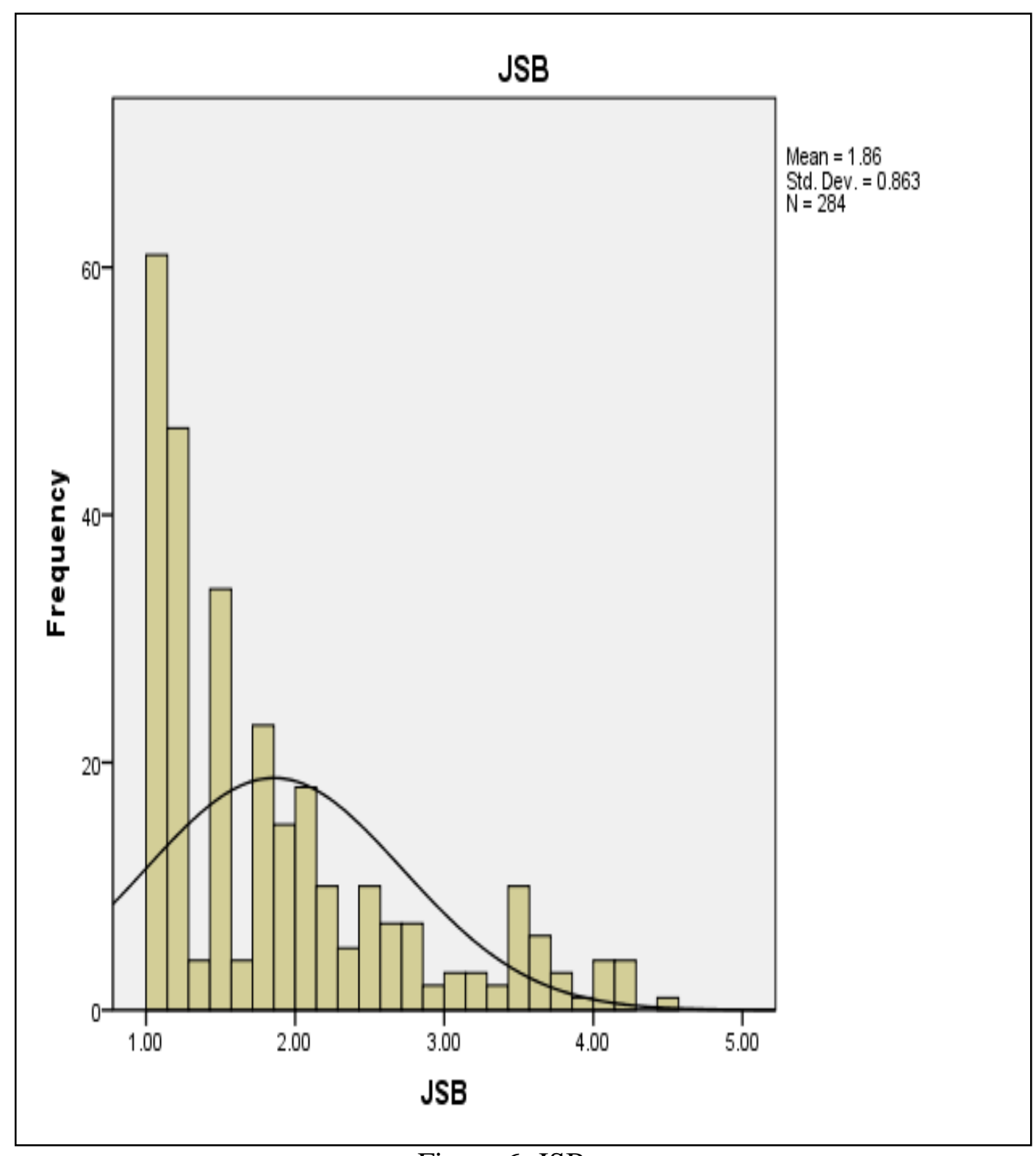

Figure 6: JSB 


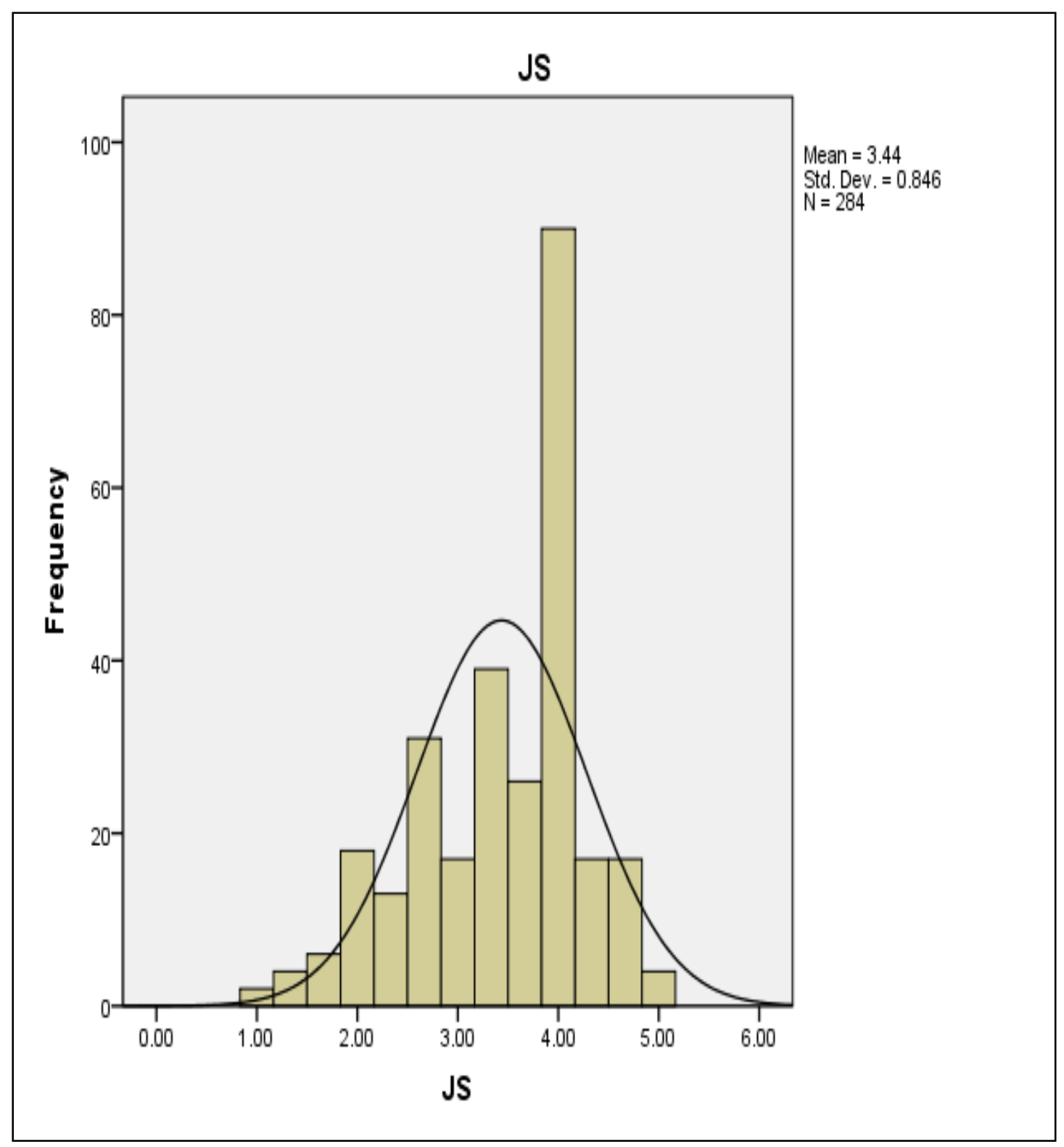

Figure 7: JS 


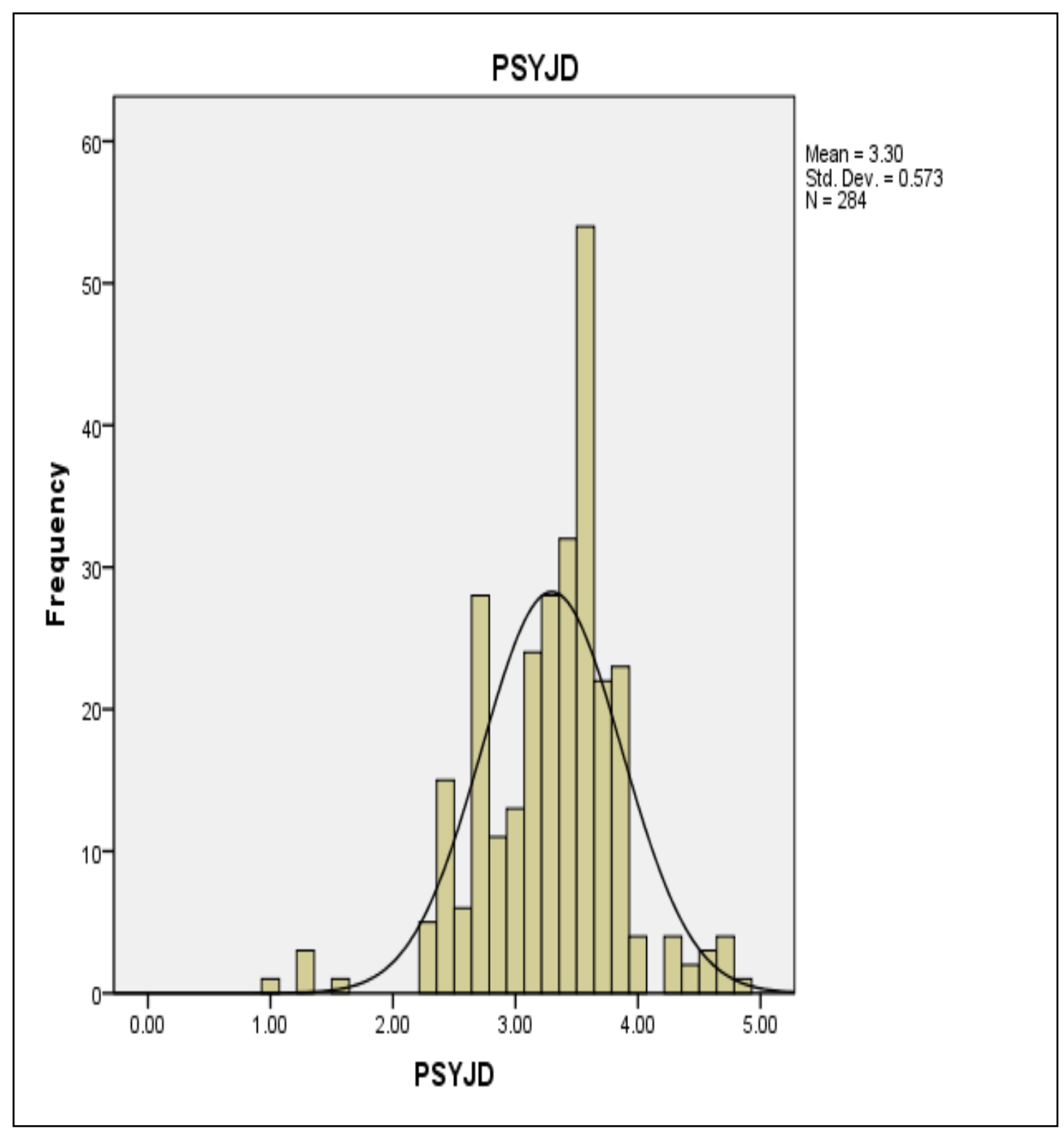

Figure 8: PSYJD

Also, linearity of dataset was confirmed that each independent assumption in the proposed conceptual model has a straight association with the outcomes constructs by checking the appropriate scatterplot. Checking the homoscedasticity also has been highlighted that the measurement items meet the assumptions by simple scatter plot with the variable on the $y$-axis and the variable's residual on the $\mathrm{x}$-axis and analyzing the normal probability plot of the regression standardized residual and the scatterplot of the standardized residuals. We checked homoscedasticity of JS, PSYJD and JSB when predicted by HPWS. When we plot the fit line, the amount of error or distance 
from the line does not increase or decrease through the fit line. If it is roughly consistent, then we have homoscedasticity. Figure 9-11.

In sum, the preliminary analytical tests results truly demonstrate that the dataset of the present research were clean from normality, linearity, and homoscedasticity issues. 


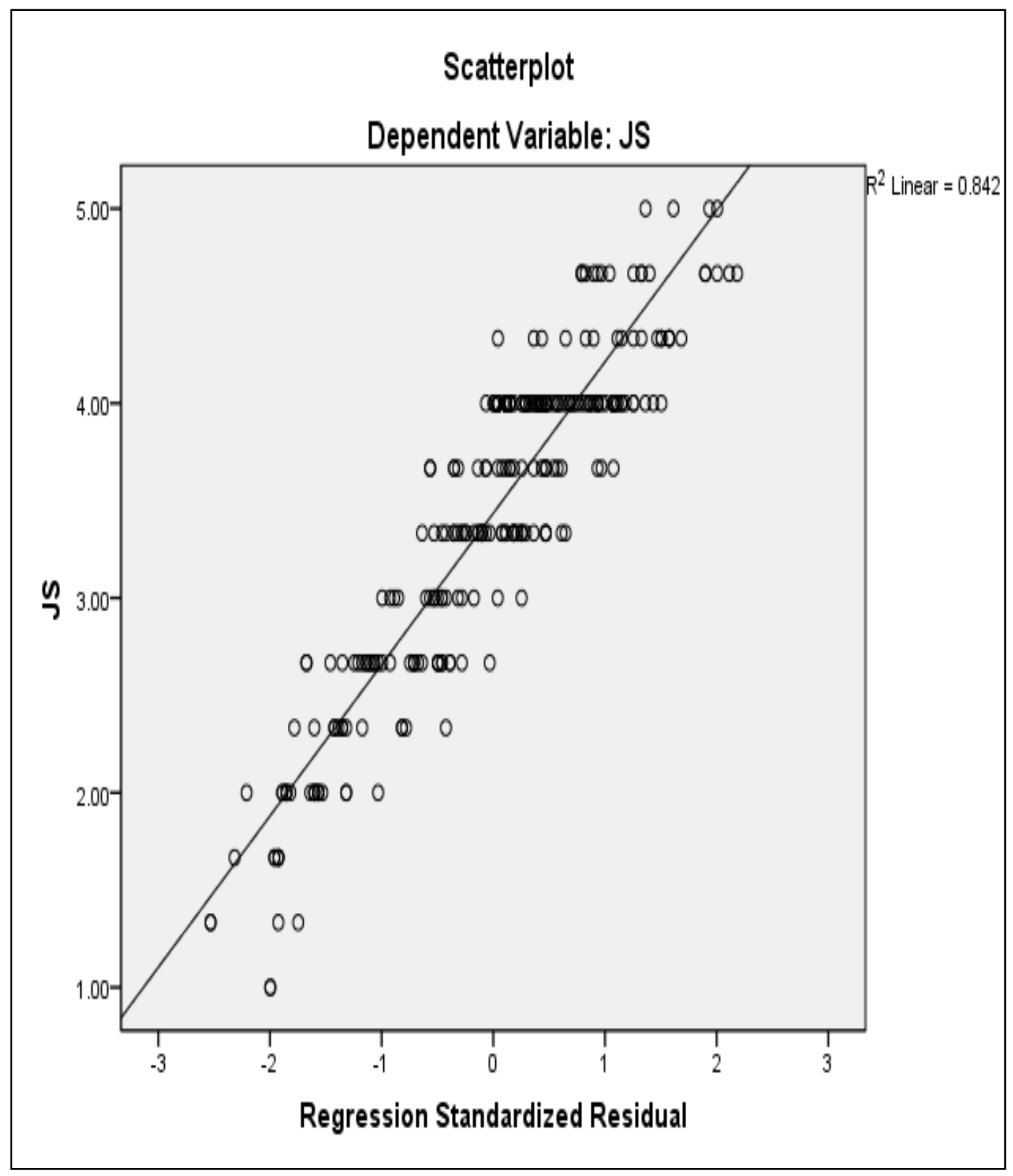

Figure 9: JS 


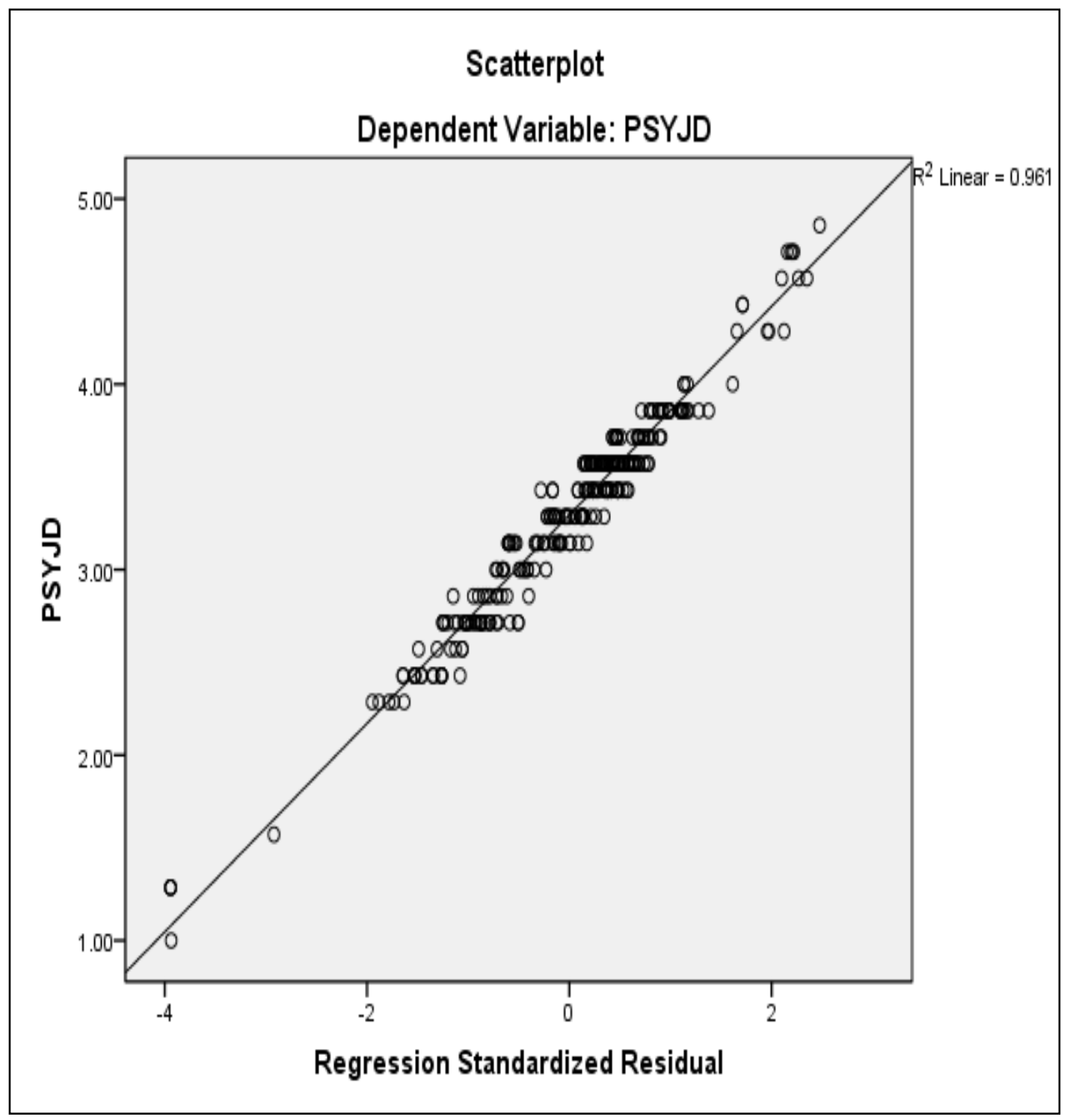

Figure 10: PSYJD 


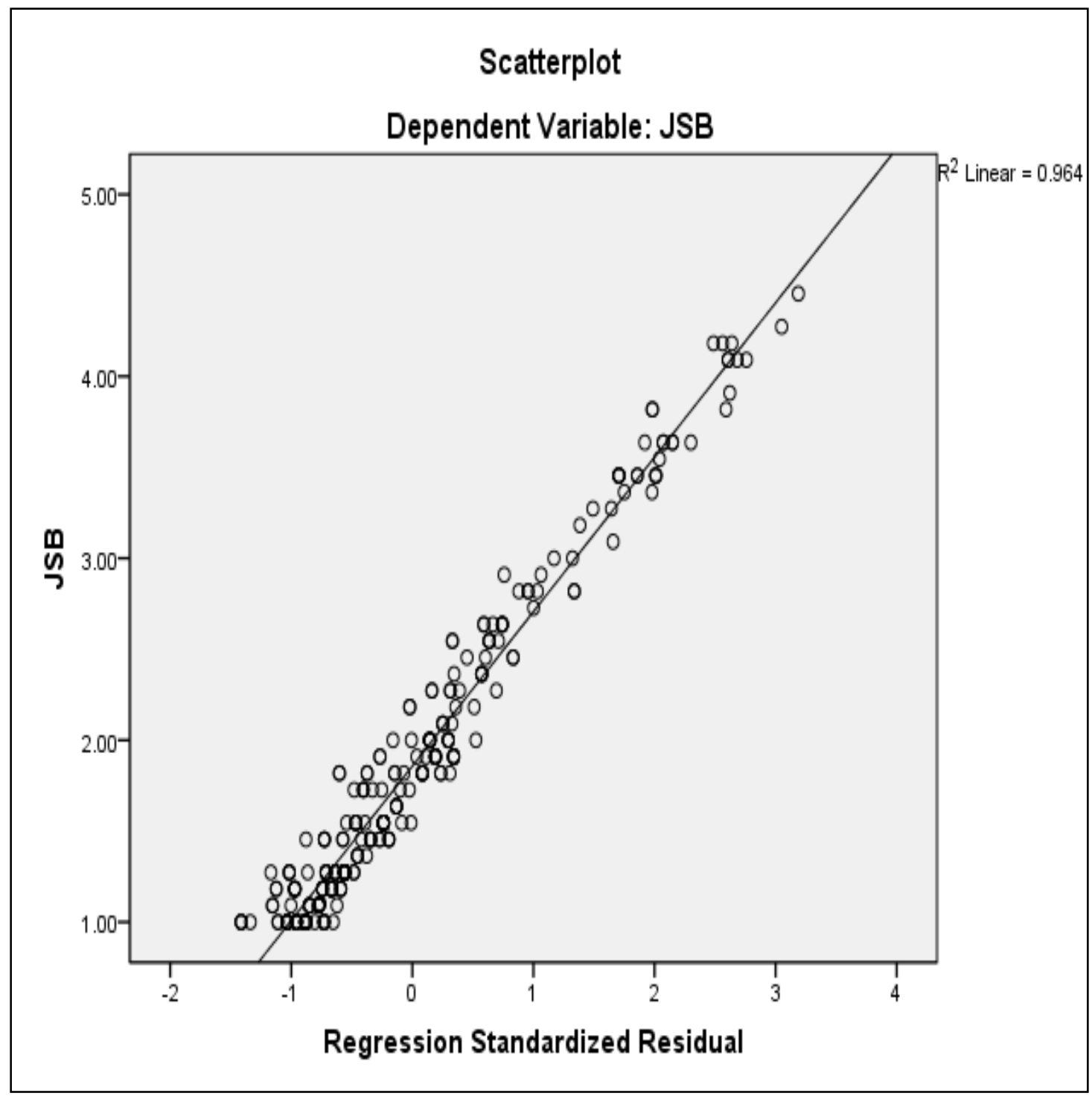

Figure 11: JSB 
First of all, a descriptive analysis was conducted to generate respondents' profiles based on the following demographic characteristics: age, gender, marital status, education level, and monthly income, and years of job tenure.

The factor analysis was conducted with varimax rotation, items with cross-loadings greater than or equal to .40 will be eliminated and Eigen value greater than 1 .

Reliability "refer to the consistency of a measure, if set of variables consistently load on same factor". We test reliability of each factor by compute Cronbach's alpha for estimating the internal consistency. Composite Reliability (CR) was also considered to check the reliability of data set. The test of discriminant validity was conducted to check whether factors are district and uncorrelated; variables should firmly load on their own factor than to another factor. Kline (2005) stated through analyzing the correlation coefficients among measured constructs, discriminant validity could be noticed. Additionally, there will be proof of discriminant validity if the value of correlation coefficients does not surpass 0.80 .

Convergent validity also was applied to examine if all variables within a single factor are highly correlated. All of the above mentioned analyses were conducted to establish convergent and discriminant validity of the items used in study.

For next step, a structural equation modeling with maximum-likelihood estimation utilizing IBM-SPSS AMOS v21 was applied to test the hypothesized relationships. Multiple regression analysis was accompanied to assess the impact of the independent variable on the mediator and the dependent variable, Thereafter, as recommended by Preacher et al., (2007) the mediating effect of the mediator was 
evaluated by using indirect effect analysis. Bootstrapping was conducted to determine the mediation effect, using 95\% confidence interval level. According abundant previous studies (e.g., Shrout \& Bolger, 2002; Preacher \& Hayes, 2004; Rucker et al., 2011) bootstrapping technique is a compelling tool to test mediation effects in comparison SOBEL test due to its ability of resampling the dataset with the aim of creating a confidence interval (CL).

One of the main advantages of bootstrapping is the inference based on an estimate of the indirect effect itself, without any assumptions about the shape of sampling distribution of the indirect effect (Hayes , 2013). Bootstrapping was used to examine the mediation effect in current study. 


\section{Chapter 5}

\section{RESEARCH FINDINGS}

This chapter illustrates the data analysis and empirical results and findings of the current study.

\subsection{Analytic Strategy and Findings}

The final sample was primarily male $(58.7 \%)$, with a mean age of 30years $(\mathrm{SD}=$ $.579)$ and an average of 8 years $(\mathrm{SD}=.755)$ at their current job. Table 2 presents respondents' profile. The sample consisted of 158 (58.7\%) males and $111(41.3 \%)$ females. Fifty-one (19\%) respondents were aged between 21 and 30 years while 187 (69.5\%) respondents were aged between 31 and 40 years and $28(10.4 \%)$ were between 41 and 50 . The rest of respondents were older than 51 years (1.1\%). In terms of education, $19(7.1 \%)$ respondents had Associate Degree; while 176 (65.4\%) respondents had Bachelor's Degree. 73(27.1\%) had Master Degree and one person had passed the Doctorate Degree (.4\%). Four respondents had tenures below one year, while $32(11.9 \%)$ respondents had tenures between one and four years. $84(31.2 \%)$ respondents had tenures between five and eight years. The rest had been with their current organization for longer than nine years. In terms of marital status, $26 \%$ of respondents were single or divorced and the rest were married. Participants had varying levels of income, about $57.2 \%$ had monthly income between $1 \mathrm{~m}$ to $1.99 \mathrm{~m}$ Toman (300-600 USD), $35.3 \%$ between $2 \mathrm{~m}$ to $2.99 \mathrm{~m}$ Toman (600-900 USD), $5.6 \%$ between $3 \mathrm{~m}$ to $3.99 \mathrm{~m}$ Toman,(900-1300 USD) and the rest less than $1 \mathrm{~m}$ Toman (300 USD) per month. 
Table 2: Respondents' Profile ( $\mathrm{n}=269)$

\begin{tabular}{|c|c|c|}
\hline Items & Frequency & Percentage \\
\hline \multicolumn{3}{|l|}{ Age } \\
\hline $21-30$ & 51 & 19.0 \\
\hline $31-40$ & 187 & 69.5 \\
\hline $41-50$ & 28 & 10.4 \\
\hline Above 51 & 3 & 1.1 \\
\hline \multicolumn{3}{|l|}{ Gender } \\
\hline Male & 158 & 58.7 \\
\hline Female & 111 & 41.3 \\
\hline \multicolumn{3}{|l|}{ Education } \\
\hline Associate Degree & 19 & 7.1 \\
\hline Bachelor's Degree & 176 & 65.4 \\
\hline Master Degree & 73 & 27.1 \\
\hline Doctorate Degree & 1 & 0.40 \\
\hline \multicolumn{3}{|l|}{ Organizational tenure } \\
\hline Below 1 year & 4 & 1.5 \\
\hline $1-4$ years & 32 & 11.9 \\
\hline $5-8$ years & 84 & 31.2 \\
\hline Above 9 years & 149 & 55.4 \\
\hline \multicolumn{3}{|l|}{ Marital Status } \\
\hline Single or divorced & 70 & 26 \\
\hline Married & 199 & 74 \\
\hline \multicolumn{3}{|l|}{ Income level } \\
\hline Less than 1 million Toman & 5 & 1.9 \\
\hline 1-1.99 million Toman & 154 & 57.2 \\
\hline 2-2.99 million Toman & 95 & 35.3 \\
\hline 3-3.99 million Toman & 15 & 5.6 \\
\hline
\end{tabular}




\begin{tabular}{|c|c|c|}
\hline & CR & SFL(t) \\
\hline High performance work systems & .83 & \\
\hline 1. "In my workplace, great effort is taken to select the right person" & & $.54(-)$ \\
\hline 2. "In my workplace, long-term employee potential is emphasized". & & $.40(5.057)$ \\
\hline 3. "In my workplace, considerable importance is placed on the staffing process". & & $.51(6.320)$ \\
\hline 4. "In my workplace, very extensive efforts are made in selection". & & $.60(8.469)$ \\
\hline 5. "In my workplace, extensive training programs are provided for individuals in customer contact or front-line jo & jobs". & _* \\
\hline 6. "Employees in customer contact jobs will normally go through training programs every few years". & & * \\
\hline 7. "There are formal training programs to teach new hires the skills they need to perform their job". & & $-*$ \\
\hline 8. "Formal training programs are offered to employees in order to increase their ability in this organization". & & -* \\
\hline 9. "Employees have few opportunities for upward mobility". (R) & & - \\
\hline 10. "Employees do not have any future in this organization". (R) & & - \\
\hline 11. "Promotion in this organization is based on seniority". (R) & & $-*$ \\
\hline 12. "Employees have clear career paths in this organization". & & $.41(5.43 \overline{4})$ \\
\hline 13. "Employees in customer contact jobs who desire promotion have more than one potential position they could $\mathrm{b}$ & be promoted to". & $.58(6.892)$ \\
\hline 14. "Employees in this job can be expected to stay with this organization for as long as they wish". & & - \\
\hline 15. "Job security is almost guaranteed to employees in this job". & & $.51(6.38 \overline{9})$ \\
\hline 16. "The duties in this job are clearly defined". & & _* \\
\hline 17. "This job has an up-to-date description". & & $.50(6.264)$ \\
\hline 18. "The job description for a position accurately describes all of the duties performed by individual employees". & & $.59(6.979)$ \\
\hline 19. "Performance is more often measured with objective quantifiable results". & & $.40(4.751)$ \\
\hline 20. "Performance appraisals are based on objective quantifiable results". & & ${ }_{-}^{*}$ \\
\hline 21. "Employee appraisals emphasize long term and group-based achievement". & & $.59(6.966)$ \\
\hline 22. "Individuals in this job receive bonuses based on the profit of the organization". & & 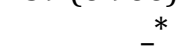 \\
\hline 23. "Close tie or matching of pay to individual/group performance". & & $.40(5.327)$ \\
\hline 24. "Employees in this job are often asked by their supervisor to participate in decisions". & & $.54(6.565)$ \\
\hline 25. "Individuals in this job are allowed to make decisions". & & $.44(5.567)$ \\
\hline 26. "Employees are provided the opportunity to suggest improvements in the way things are done". & & $.45(5.800)$ \\
\hline 27. "Supervisors keep open communications with employees in this job" & & $.40(5.325)$ \\
\hline
\end{tabular}

Note - denotes item discarded due to its high cross-loading (> 0.40). Forced to a four-factor solution. 
Table 3 (cont): Results of Factor Analysis

\begin{tabular}{|c|c|c|c|}
\hline & CR & $\boldsymbol{\alpha}$ & SFL(t) \\
\hline 1. "Made inquiries/read about getting a job" & & & $*(-)$ \\
\hline 2. "Prepared/revised resume" & & & $.75(12.882)$ \\
\hline 3. "Read classified/help wanted advertisements", & & & $.76(13.229)$ \\
\hline 5. "Spoke with previous employers or business acquaintances about possible job leads" & & & $.59(9.936)$ \\
\hline 6. "Visited job fairs, contacted employment agencies" & & & $.56(9.265)$ \\
\hline 7. "Looked for jobs on the internet" & & & $.82(14.480)$ \\
\hline 8. "Made inquiries to prospective employers" & & & $.93(16.761)$ \\
\hline 11. "Listed yourself as a job applicant in a newspaper, journal or professional association" & & & $.76(-)$ \\
\hline Job Satisfaction & .86 & .85 & \\
\hline 1. "I feel fairly well satisfied with my present line" & & & $.93(-)$ \\
\hline 2. "I feel a great sense of satisfaction from my line" & & & $.80(14.810)$ \\
\hline 3. "All things considered (i.e., pay, promotion, supervisors, co- workers, etc.), how satisfied are you v & ur pre & work?" & $.73(13.318)$ \\
\hline Job Demand & .77 & .76 & \\
\hline 5. "I am not asked to do an excessive amount of work" & & & $*(-)$ \\
\hline 6. "My job is very hectic" & & & $.75(8.256)$ \\
\hline 7. "Waiting on work from other people or departments often slows me down on my job" & & & $.48(6.183)$ \\
\hline
\end{tabular}

Notes: -* dropped items during confirmatory factor analysis 
All empirical indicators (measured variables) are loaded highly on only one factor by a "factor loading estimate" and each measured variables has smaller loading (cross loading) on other factors (i.e. loading less than 0.40) (Hair et al.,1998)

By using principal component with varimax rotation each factor loading in table 3 , excluding 11 items from the HPWS measure, 1 item from Job Search Behavior, 2 items from Job Demand were discarded due to low and/or cross loading. Consequently, the results produced four factors with eigenvalues greater than 1.00.

In addition, for the scale reliability and validity, Cronbach's alphas $(\alpha)$ exceeded the recommended values of .70 for all constructs (Nunnally, 1978), which indicated a high degree of internal consistency. Accordingly, composite reliability (CR) was also greater than the threshold value of .60 (Bagozzi, \& Phillips, 1991). The test for discriminant validity applied Fornell and Larcker's (1981) criterion for correlation coefficients, which were all below .80 (Kline, 1998, 2005). The standardized factor loadings were equal and/or exceeded the recommended value .40 (Bagozzi \& Baumgartner, 1994). Overall, this provides evidence and confirm of construct, convergent and discriminant validity. More details are available in table 3. 
Table 4: Means, Standard Deviations (SD), and Correlations of Study Variables

\begin{tabular}{|c|c|c|c|c|c|c|c|c|c|c|c|}
\hline Variables & Mean (SD) & 1 & 2 & 3 & 4 & 5 & 6 & 7 & 8 & 9 & 10 \\
\hline 2. Age & $2.94_{(.58)}$ & -.078 & - & & & & & & & & \\
\hline 4. Income & $2.45_{(.63)}$ & -.066 & $.231^{* *}$ & $.151^{* *}$ & - & & & & & & \\
\hline 5. Education & $2.21_{(.56)}$ & -.055 & $-.120^{*}$ & -.097 & $.275^{* *}$ & - & & & & & \\
\hline 7. High-performance work system & $3.01_{(.51)}$ & -.093 & -.021 & -.002 & .055 & -.044 & -.117 & - & & & \\
\hline 8. Job satisfaction & $3.45_{(.83)}$ & .062 & -.100 & .002 & .074 & -.020 & -.065 & $.386^{* *}$ & - & & \\
\hline 9. Physiological job demand & $3.33_{(.68)}$ & -.032 & .022 & $.153^{*}$ & -.058 & -.025 & .022 & $.130^{*}$ & .087 & - & \\
\hline 10. Job search behavior & $1.77_{(.81)}$ & -.053 & -.108 & $-.203^{* *}$ & -.014 & .073 & $-.210^{* *}$ & .041 & $-.191^{* *}$. & .003 & - \\
\hline
\end{tabular}

Note: Composite scores for each variable were computed by averaging respective item scores. SD, standard deviation; ** Correlations are significant at the .01 level 
Variable means, standard deviations and inter-correlations are reported in table 4. The path correlation coefficient among HPWS, Job satisfaction, physiological job demand and job search behavior were significant. The demographic variables were used as control variables. Demographic data apprehended for current study are gender, age, marital status, income level, education and tenure. Control variables are usually variables that we are not the most interested in, but these demographic characteristics might have severe interactions with the criterion (dependent variables). We want to eliminate their effects from the equation. The inter-correlation coefficients in table 4 prove that there are no prominent association between measured variables in our study and control variables. A few numbers of associations were uncovered.

Confirmatory Factor Analysis (CFA) is a statistical method to test how well measured variables are representing a smaller number of composite factors (latent variables) or constructs. Applying CFA statistics as a confirmatory test can indicate us how well the measured variables systematically and logically are representing the construct of our theoretical model. Apparently, CFA is a tool that helps us to either "reject" or "confirm" our preconceived theory. On the contrary of EFA which the factors are derived from statistical results, not from the theory. (Hair et al., 2002)

Structural Equation Modeling (SEM) is a combination of factor analysis and multiple regression analysis to examine how things are related to each other. In our study, a structural equation modeling with maximum-likelihood estimation utilizing IBMSPSS AMOS v21 was used to test the hypothesized relationships. To enable model identification, we tested the data with various models, with a fully mediated (two mediators), (one mediator) and single model, model comparison was done using the 
$\chi^{2}$ difference test. A confirmatory factor analysis (CFA) indicated a four factor solution, $(\chi 2(513)=1269.29, \mathrm{p}<.01 ; \mathrm{GFI}=.80, \mathrm{CFI}=.83, \mathrm{TLI}=.81, \mathrm{RMSEA}=$ $.07)$ fit the data significantly better than a three factor solution where the mediators were forced to load on a single factor $(\chi 2(516)=1698.00, \mathrm{p}<.01 ; \mathrm{GFI}=.73, \mathrm{CFI}=$ .73 , TLI $=.71$, RMSEA $=.09)$, as well as a single-factor solution $(\chi 2(527)=$ 2918.65, $\mathrm{p}<.01 ; \mathrm{GFI}=.50, \mathrm{CFI}=.46, \mathrm{TLI}=.43, \mathrm{RMSEA}=.13)$. Overall, this study utilized a time lag design, the change in chi-square value between the aforementioned models and the poor model fit indices for a single factor model suggest that common method variance does not seem to be a problem (Podsakoff \& MacKenzie, 2012). See Table. 
Table 5: Model Fit Indices

\begin{tabular}{|c|c|c|c|c|c|}
\hline & $\chi 2_{(d f)}$ & CFI & TLI & RMSEA & Relative $\chi 2$ \\
\hline 1-Factor Model & $2918.65_{(527)}$ & .50 & .46 & .43 & $.13 \quad 5.54$ \\
\hline $\begin{array}{l}\text { 3-Factor Model } \\
\text { HPWS } \\
\text { Job search behavior } \\
\text { Job satisfaction + Physiological job den }\end{array}$ & $1698.00_{(516)}$ & .73 & .73 & .71 & $.09 \quad 3.29$ \\
\hline $\begin{array}{l}\text { Measurement Model } \\
\text { HPWS } \\
\text { Job satisfaction } \\
\text { Job search behavior } \\
\text { Physiological job demand }\end{array}$ & $1269.29_{(513)}$ & .80 & .83 & .81 & 2.47 \\
\hline
\end{tabular}

Note: $\chi 2$, Model Chi Square; df, degree of freedom; GFI, Goodness of Fit; CFI, Comparative Fit Index; TLI, Tucker Lewis Index; RMSEA, Root Mean Square Error of Approximation; Relative $\chi 2, \chi^{2} / \mathrm{df}$ 
Hypothesis 1 proposed that HPWS is associated with job satisfaction. HPWS influence employees job satisfaction positively $(\beta=.627, \rho=.000)$. Thus, hypothesis 1 was supported. Next, this study hypothesized that HPWS is related with physiological job demand. HPWS influences physiological job demand positively $(\beta=.172, \rho=.032)$ thus, hypothesis 2 was supported. Hypothesis 3 predicts that employee job satisfaction will influence their job search behaviors. Consistent with our prediction, employee job satisfaction relates with job search behavior negatively $(\beta=-.238, \rho=.000)$ thus, hypothesis 3 was supported. Finally, we predicted that physiological job demand will influence employee's job search behaviors, we uncover a non-significant relationship between the aforementioned variables $(\beta=.008, \rho=.911)$ thus, hypothesis 5 was rejected. See table 6 .

This paper hypothesized that job satisfaction and physiological job demand will mediate the relationship between HPWS and job search behavior. To augment the evidence of the indirect effect, we bootstrapped the model to produce a biascorrected confidence interval (BC) for the standardized parameter estimate (Preacher \& Hayes, 2004; Hayes, 2013) utilizing a validation sample of $(n=2,000)$. We uncover that HPWS has a significant indirect effect on job search behavior through job satisfaction $(\beta=-.148, \mathrm{p}=.000)$ with a $\mathrm{BC}$ estimates at $(\mathrm{p}=.000,95 \%$ confidence interval: -.157 - -.047). We also uncover that physiological job demand does not mediate the relationship between HPWS and job search behavior. Thus, hypothesis 4 was supported and 6 rejected. See table 7. 
Table 6: Maximum Likelihood Estimates for the Research Model

\begin{tabular}{|c|c|c|c|c|c|}
\hline $\begin{array}{l}\text { Predictor } \\
\text { Variables }\end{array}$ & $\begin{array}{c}\text { Criterion } \\
\text { Variables }\end{array}$ & $\begin{array}{c}\beta \text { eta } \\
\text { Coefficients }\end{array}$ & $\begin{array}{l}\text { Standard } \\
\text { Error }\end{array}$ & t-value & $p$ \\
\hline High-performance work systems & Job satisfaction & .627 & .091 & 6.857 & $* * *$ \\
\hline High-performance work systems & Physiological job demand & .172 & .080 & 2.148 & $.032^{* *}$ \\
\hline High-performance work systems & Job search behavior & .213 & .103 & 2.069 & $.039^{* *}$ \\
\hline Job satisfaction & Job search behavior & -.238 & .063 & -3.777 & $* * *$ \\
\hline Physiological job demand & Job search behavior & .008 & .072 & 0.112 & .911 \\
\hline
\end{tabular}

Notes: ${ }^{* * *}$ Significant at the $\mathrm{p}<0.05$ level (two-tailed); ${ }^{* * *}$ Significant at the $\mathrm{p}<0.01$ level (two-tailed) 
Table 7: Research model effect distribution

\begin{tabular}{llllll}
\hline $\begin{array}{l}\text { Predictor } \\
\text { Variables }\end{array}$ & $\begin{array}{l}\text { Criterion } \\
\text { Variables }\end{array}$ & $\begin{array}{l}\text { Total } \\
\text { Effect }\end{array}$ & $\begin{array}{l}\text { Direct } \\
\text { Effect }\end{array}$ & $\begin{array}{l}\text { Indirect } \\
\text { Effect }\end{array}$ & $\begin{array}{l}\text { Confidence Interval } \\
\text { [LO }- \text { UP] }\end{array}$ \\
\hline & & & & & \\
High-performance work systems & Job satisfaction & .627 & .627 & .000 & \\
High-performance work systems & Physiological job demand & .172 & .172 & .000 & \\
High-performance work systems & Job search behavior & .065 & .213 & $\mathbf{- . 1 4 8}$ & {$[-.157$ to -.047$] .001$} \\
Job satisfaction & Job search behavior & -.238 & -.238 & .000 & .000 \\
Physiological job demand & Job search behavior & .008 & .008 & .000 &
\end{tabular}

Notes: LO, lower bound; UP, upper bound; "Significant at the $\mathrm{p}<0.05$ level (two-tailed); ${ }^{* * *}$ Significant at the $\mathrm{p}<0.01$ level (two-tailed 


\section{Chapter 6}

\section{DISCUSSION AND CONCLUSIONS}

This last part of our research comprises of the discussion about the results obtained in the previous chapter related to the proposed research hypotheses, as well as the conclusion for the overall study. The chapter sections are as follow: Discussion, Theoretical and Practical Implications, and Limitations and Future Directions.

\subsection{Discussion}

Even though the relationship between HPWS and employee attitudes and behaviors is well established, less is known about mechanisms that underline the relationship between HRM practices and job search behavior as a negative phenomenon in organizations. To the best of our knowledge, this is the first study to examine the mediation effects of job demand and job satisfaction on the relationship between HPWS and JSB in Iran. By analyzing the proposed relationship, this study relied on COR theory; that people seek to obtain and maintain resources, and if a loss or threat of loss happens, stress will occur which in turn will affect attitude and behavior of individuals.

As predicted, results indicate that HPWS enhanced job satisfaction, which in turn led to decreased JSB. The direct positive relationship between HPWS and JS is consistent with COR theory, which suggests that different resources such as social support, team working climate, training, feedback, job security and promotions influence employee attitudes like job satisfaction. This confirms that HPWS 
enhances satisfaction by creating favorable experiences such as providing social support, more financial or job security, opportunities for promotion and rewards. Job satisfaction appears as a key variable in the relationship between HPWS and JSB as it fully mediated the relationship between HPWS and the criterion variable. Thus, HPWS are related to employee's JSB because they have an influence on employee's attitude. We can say that the employee psychological outcome could serve as a potential mediating link that has been neglected in HPWS research when examining negative employee behaviors at workplace. COR theory states that HPWS can influence employee's JSB via employee attitudes such as job satisfaction through gain or loss of resources (Lee \& Mitchel, 1994).

Consistent with prior research, the findings reveal that there is a positive relationship between HPWS and job demand (Ramsay et al., 2000). Employees subjected to HPWS might experience higher level of stress compared to other employees due to increased possibilities of imposing strains due to stress and intensity of organizations. This is also consistent with COR theory which proposes that applying more HPWS and demanding higher responsibilities could lead to higher intensification which would increase stress as psychological cost in workplace. Job demand doesn't seem to have mediation effect on the relationship between HPWS and job search behavior as the achieved result fails to support a mediating relationship.

Therefore, the last hypothesis wasn't supported. HPWS, appear to influence JSB only via the optimistic pathway of HRM practices. This suggests that employees who are exposed by high job demand do not necessarily engage in the search for alternative jobs. Perhaps societies such as Iran, people have the perception that their 
actions are restrained and controlled by strict social norms and rules. Furthermore, they accept the hierarchical order in the workplace and expect to receive very specific and clear instructions on what to do and they are willing to accept the benevolent autocrat. So, this cultural characteristic may be related to our result that high level of job-demand in their workplace does not lead to job search. An alternative explanation may be based on COR theory, stress may occur due to imbalance between job demands and resources, but some job resources might compensate for some effects of job demand on employee's behavior (Bakker, 2007). This finding implies that the attitudinal mechanisms of HRM's influence could offset the negative impact of high job demand. This means that if implementation of HPWS practices joined with an appropriate improvement in employee's attitude and psychological aspects, these set of HR practices can decrease the negative effect of HPWS such as stress and work overload on employees' perception about the workplace where they are working.

Additionally, from cultural point of view, HPWS' effects on employees' attitude and behaviors may vary in different cultural contexts. Islamic values urge workers to be committed and loyal and do their best in organization (Habib R. \& Malik, 2016). Based on religious perspective, workplace's relationships in Iran go beyond the written and psychological contracts between employers and employees. The Islamic context may require HRM systems to have more focus on the employee human being and not just the transactional relationship between the employee and the employer. Contrary to the western notion of the "Weberian ideal type" bureaucratic system where impersonality and position descriptions are expected to create an ideal mechanic organization with the employees as the component parts serving their roles (Walton, 2005), the Islamic context requires HPWS to focus more on the whole 
individual rather than only consider them with regard to their current duties in the organization. In the Iranian context, a HPWS that is imitated from western examples without considering the context, may lead to some undesirable outcomes where the employee is overburdened with certain activities without appreciating the benefits for their own wellbeing.

\subsection{Theoretical and Practical Implications}

The findings of this study offer some implications for mangers. The study shows that HPWS is related to job satisfaction which in turn is linked to reduced unwanted organizational outcomes such as "job search behavior". The study sheds light on how managers can invest in HR practices to retain talented employees. Consistent with COR theory, HRM practices can be considered as helpful and effective resources in organizations to reduce negative effects of various job demands (Bartram et al., 2012). In other words, it is possible to alleviate negative impacts of job demand if job resources are available and can buffer various negative aspects of job demand. For instance, HPWS' features such as selective hiring and proper training can help individuals to cope with challenges easier, especially in emotionally demanding situations (Xanthopoulou et al., 2007).

In recent years, the emergence of an alternative theoretical perspective to challenge HPWS has emerged. This perspective argues that HPWS which is intended to create a competitive advantage for organization may in fact result in neglect of the individual employee's needs and cause work overload, increasing pressure on the individual and burnout (Barney \& Wright, 1997). Employee psychological or behavioral outcomes are either ignored or sacrificed for achieving the organizational goals (Sparham \& Sung, 2007). Extant literature highlights some evidence for 
negative impact of HPWS when managerial strategies to control workers behaviors and efforts are exacerbated (Ramsey et al., 2000). It has been reported that implementation of HR practices which consider employees merely as a component in the organizational system mainly manifest strains which is caused by the intensity of work stress (Chaudhuri, 2009). Moreover, HPWS can intensify workload, increase job pressures, and lead to greater exhaustion (Gulzar et al., 2014), job insecurity, and declining influence on the job can reduce quality of work life (Kumar, 2000). Therefore, more employee-centered research considering HPWS's effects on employee psychological and behavioral outcomes (Fan 2014; Gulzar et al., 2014) should be carried out to investigate the complex nature of how HPWS is related to employee outcomes. In our study, we tried to have a closer look at the employee perspective on HPWS and investigate whether perceived HPWS have some negative psychological outcomes. The results of our study can provide necessary information for decision makers and practitioners to determine the most effective set of high performance work practices.

Constructive feedback reduces the effects of physical demand and helps employees to do their job effectively and therefore enhances their performance. Policy makers and managers should attempt to set the best fit bundle of HR practices and allocate enough resources in their implementation HPWS. Managers should also focus on how to appraise and compensate employee performance, to involve them in decision making and to develop team-work in order to enhance motivation. They can apply restorative techniques such as job design and training. We also encourage management to respect the organizational chart, employees' position and authority in respect to promotions. 
The clear message of this study is that managers should balance between job demands - resources in workplace and provide adequate resources for their employees to buffer specific negative effects of job demands. Sometimes a simple job resource is enough and helpful. For instance, social support by other colleagues and supervisors, providing recreation opportunity or even scheduling flexibility (sunshine morning) to avoid commuting during rush hours which could lead to positive outcomes due to improvement of job resources that diminish the negative effects of job demands.

\subsection{Limitations and Future Directions}

The present study has several limitations that are worth mentioning, although, this study measured employee perception of HPWS and the other employee-rated variables using two-time lag to reduce the potential effect of CMV, a time lag designed study that solicits multi-source data would provide better insights and also test for homology (Chen et al., 2005) among the predictor and criterion variables. Respondents tend to overreport in referent or informant and underreport in selfreports approach, to bypass this, a mixed method approach is recommended (Alam \& Bhatti, 2018). Given the momentum gained by artificial intelligence, machine learning e.g., artificial neural network approaches can be utilized in future study as proposed by (Abubakar, 2018; Abubakar et al., 2018, 2019; Leong et al., 2015; Sim et al., 2014). Future research can also examine the diverse performance outcomes related to the three components/bundles of the AMO model using the above proposed methodological approaches. According to Kundu et al. (2016), AMOenhancing HR practices can help organization to create "employees" as a source of competitive advantage. Last but not the least, our study examines these phenomenon in private banks, findings from public banks would provide useful insights. 


\section{REFERENCES}

Abubakar, A. M. (2018). Linking work-family interference, workplace incivility, gender and psychological distress. Journal of Management Development, 37(3), 226-242.

Abubakar, A. M., Karadal, H., Bayighomog, S. W., \& Merdan, E. (2018). Workplace injuries, safety climate and behaviors: application of an artificial neural network. International journal of occupational safety and ergonomics, 1-11.

Abubakar, A. M., Megeirhi, H. A., \& Shneikat, B. (2018). Tolerance for workplace incivility, employee cynicism and job search behavior. The Service Industries Journal, 38(9-10), 629-643.

Abubakar, A.M., Yazdian, T.F., \& Megdadi, K. J. (2019). An Integrative Review: High-Performance Work Systems, Psychological Capital and Future Time Perspective. International Journal of Organizational Analysis.

Ahmad, M. (1995), Business Ethics in Islam, The International Institute of Islamic Thought, Islamabad.

Alam, M. A., \& Bhatti, O. K. (2018). Curtailing data biases in business research: Introducing a hybrid approach. Journal of Management \& Organization,1-15.

Alarcon, G. M. (2011). A meta-analysis of burnout with job demands, resources, and attitudes. Journal of Vocational Behavior, 79(2), 549-562. 
Ali, A. J. (2009). Levels of existence and motivation in Islam. Journal of Management History, 15(1), 50-65.

Ali, A.J. (2010). Islamic challenges to HR in modern organizations. Personnel Review, 39(3), 278-302.

Ali, A.J., \& Al-Kazemi, A.A. (2007). Islamic work ethic in Kuwait”, Cross Cultural Management: An International Journal, 14(2), 93-104.

Appelbaum, E., Bailey, T., Berg, P. B., Kalleberg, A. L., \& Bailey, T. A. (2000). Manufacturing advantage: Why high-performance work systems pay off. Cornell University Press.

Armstrong, S. J., \& Overton, T. S. 1977. Estimating non-response bias in mail surveys. Journal of Marketing Research, 14(1), 396-402.

Ashill, N. J., Rod, M., \& Carruthers, J. (2008). The effect of management commitment to service quality on frontline employees' job attitudes, turnover intentions and service recovery performance in a new public management context. Journal of Strategic Marketing, 16(5), 437-462. https://doi.org/10.1080/09652540802480944.

Askari, H., Iqbal, Z. and Mirakhor, A. (2014). "Economic and social justice: the policy objective in Islam", Challenges in Economic and Financial Policy Formulation, Palgrave Macmillan, pp. 31-46. 
Ayentimi, D. T., Burgess, J., \& Brown, K. (2018). HRM practices of MNEs and domestic firms in Ghana: divergence or convergence? Personnel Review, 47(1), 2-21.

Bagozzi, R. P., \& Baumgartner, H. (1994). The evaluation of structural equation models and hypothesis testing. In Bagozzi RP (Ed.), Principles of marketing research (pp. 386-422). Cambridge: Blackwell Publishers.

Bagozzi, R. P., Yi, Y., \& Phillips, L.W. (1991). Assessing construct validity in organizational research. Administrative Science Quarterly, 36(3), 421-458.

Bakker, A.B., \& Demerouti, E. (2007). The job demands-resources model: state of the art. Journal of Managerial Psychology, 22(3), 309-328.

Bakker, A.B., Demerouti, E., Euwema, M.C., 2005. Job resources buffer the impact of job demands on burnout. Journal of Occupational Health Psychology 10, $170-180$.

Banks and Credit Institutions information, (2018). Retrieved from https://www.cbi.ir/simplelist/2390.aspx.

Barber, A. E., Daly, C. L., Giannantonio, C. M., \& Phillips, J. M. (1994). Job search activities: An examination of changes over time. Personnel Psychology, 47(4), 739-766. 
Barney, J.B., \& Wright, P.M. (1997). On becoming a strategic partner: The role of human resource in giving competitive advantage. (CHHRS Working Paper 97 - 07). Itlaca, Ny: Cornell University, School of Industrial Labour Relations, Center for Advanced Human Resource Studies. http://digitalcommons.ilr.cornell.edu/cahrsiop/150 4/7/2012.

Bartram, T., Casimir, G., Djurkovic, N., Leggat, S. G., \& Stanton, P. (2012). Do perceived high performance work systems influence the relationship between emotional labor, burnout and intention to leave? A study of Australian nurses. Journal of Advanced Nursing, 68(7), 1567-1578.

Batt, R. (2002). Managing customer services: Human resource practices, quit rates, and sales growth. Academy of management Journal, 45(3), 587-597.

Becker, B. E., \& Gerhart, B. (1996). 'The impact of human resource management on organizational performance: progress and prospects'. Academy of Management Journal, 39, 779-801.

Becker, B., \& Huselid, M. A. (1998). High performance work systems and firm performance: A synthesis of research and managerial implications. Research in Personnel and Human Resource Management, 16, 53-101.

Behdad, S. (2000). From populism to economic liberalism: the Iranian predicament. The economy of Iran: Dilemmas of an Islamic state, 100-141.

Blair, W. S. (1964). How subject matter can bias a mail survey. Media/Scope, 70-72. 
Blau, G. (1994). Testing a two-dimensional measure of job search behavior. Organizational Behavior and Human Decision Processes, 59, 288-312.

Boselie, P. and Dietz, G. and Boon, C. 2005 Commonalities and contradictions inresearch on human resource management and performance. Human resource management journal, 15 (3). pp. 67-94.

Boselie, P., Paauwe, J., \& Richardson, R. 2003. Human resource management, institutionalization and organizational performance: A comparison of hospitals, hotels and local government. International Journal of Human Resource Management, 14(1), 1407-1429.

Boswell, W., Zimmerman, R., \& Swider, B. (2012). Employee Job Search: Toward an Understanding of Search Context and Search Objectives. Journal of Management, 38(1).

Bowen, D. E., \& Ostroff, C. (2004). Understanding HRM-firm performance linkages: The role of the "strength" of the HRM system. Academy of management review, 29(2), 203-221.

Bretz, R. D., Boudreau, J. W., \& Judge, T. A. (1994). Job search behavior of employed managers. Personnel Psychology, 47(2), 275-301.

Brief, A. P. (1998). Attitudes in and around organizations. Thousand Oaks, CA: Sage 
Budhwar, P. S., \& Varma, A. (2011). Emerging HR management trends in India and the way forward. Organizational Dynamics, 4(40), 317-325.

Chaudhuri, K. (2009). A Discussion on HPWS Perception and Employee Behavior. Global Business and Management Research: An International Journal, 1, 2742.

Chen, G., Bliese, P. D., \& Mathieu, J. E. (2005). Conceptual framework and statistical procedures for delineating and testing multilevel theories of homology. Organizational Research Methods, 8, 375-409.

Cheng, Y.S., Liu, Y.P., \& Chien, C.Y. (2009). The association between auditor quality and human capital. Managerial Auditing Journal, 24(6), 523-541.

Chiang, Y. H., Hsu, C. C., \& Shih, H. A. (2014). Experienced high-performance work system, extroversion personality, and creativity performance. Asia Pacific Journal of Management, 32, 531-549.

Chuang, C., \& Liao, H. (2010). Strategic Human Resource Management in Service Context: Taking Care of Business by Taking Care of Employees and Customers. Personnel Psychology, 63, 153-196.

Colbert, B. A. (2004). The complex resource-based view: Implications for theory and practice in strategic human resource management. Academy of management review, 29(3), 341-358. 
Collier, J. E., \& Bienstock, C. C. (2007). An analysis of how nonresponse error is assessed in academic marketing research. Marketing theory, 7(2),

Combs, J., Lui, Y., Hall, A., \& Ketchen, D. (2006). 'How much do high-performance work practices matter? A meta-analysis of their effects on organizational performance'. Personnel Psychology, 59, 501- 28.

Cranny, C. J., Smith, P. C., \& Stone, E. F. (1992). Job satisfaction: how people feel about their jobs and how it affects their performance. New York: Lexington Press.

Delery, J. E., \& Doty, D. H. (1996). Modes of theorizing in strategic human resource management: Tests of universalistic, contingency, and configurational performance predictions. Academy of management Journal, 39(4), 802835.

Demerouti E., Bakker A.B., Nachreiner F. \& Schaufeli W.B. (2001) The job demands-resources model of burnout. Journal of Applied Psychology 86(3), $499-512$.

Den Hartog, D. N., Boon, C., Verburg, R. M., \& Croon, M. A. (2013). HRM, communication, satisfaction, and perceived performance: A cross-level test. Journal of management, 39(6), 1637-1665.

Devens R. (1988). Employment and unemployment in the first half of 1988. Monthly Labor Review, 100, 15-19. 
Estiri, M., Hosseini, F., Yazdani, H., \& Javidan Nejad, H. (2011). Determinants of customer satisfaction in Islamic banking: evidence from Iran. International Journal of Islamic and Middle Eastern Finance and Management, 4(4), 295 307. http://doi.org/10.1108/17538391111186546.

Fan, D., Cui, L., Zhang, M. M., Zhu, C. J., Härtel, C. E., \& Nyland, C. (2014). Influence of high performance work systems on employee subjective well being and job burnout: empirical evidence from the Chinese healthcare sector. The International Journal of Human Resource Management, 25(7), 931-950.

Fesharaki, F., \& Sehhat, S. (2018). Islamic human resource management (iHRM) enhancing organizational justice and employees' commitment: Case of a Qard al-Hasan bank in Iran. Journal of Islamic Marketing, 9(1), 204-218.

Fornell, C., \& Larcker, D. F. (1981). Evaluating structural equation models with unobservable variables and measurement error. Journal of Marketing Research, 18(1), 39-50.

García-Chas, R., Neira-Fontela, E., \& Varela-Neira, C. (2016). High-performance work systems and job satisfaction: a multilevel model. Journal of Managerial Psychology, 31(2), 451-466.

George, D., \& Mallery, M. (2010). SPSS for Windows Step by Step: A Simple Guide and Reference, 17.0 update (10a ed.) Boston: Pearson. 
Greener, S. (2008). Business research methods. BookBoon.

Greenwood, M.R. (2002). Ethics and HRM: a review and conceptual analysis. Journal of Business Ethics, 36, 261-78.

Gulzar, S. Moon, M.A., Attiq, S. \& Azam, R. (2014). 'The Darker Side of High Performance Work Systems: Examining Employee Psychological Outcomes and Counterproductive Work Behaviour', Pakistan Journal of Commerce and Social Sciences, 8(3), 715-732.

Guthrie, J. P., Datta, D. K. and Wright, P. M. 2004. Peeling back the onion competitive advantage through people: Test of a causal model. CAHRS Working Paper Series No. 15. Cornell University.

Habib Rana, M., \& Shaukat Malik, M. (2016). Human resource management from an Islamic perspective: a contemporary literature review. International Journal Islamic and Middle Eastern Finance and Management. 9(1), 109-124.

Habibi, S., \& Mohammadi, M. (2016). Corruption, cronyism and flawed supervision: banes of banking system. Retrieved from http://en.mehrnews.com/news/120726/Corruption-cronyism-and-flawed supervision-banes-of-banking.

Hair, J. F., Anderson, R. E., Tatham, R. L., \& Black, W. C. (1998). Multivariate data analysis. 1998. Upper Saddle River. 
Halbesleben, J.R.B., \& Buckley, M.R. (2004). Burnout in organizational life. Journal of Management, 30, 859-79.

Harley, B., Allen, B. C., \& Sargent, L. D. (2007). High performance work systems and employee experience of work in the service sector: The case of aged care. British Journal of Industrial Relations, 45(3), 607-633.

Harley, B., Sargent, L., \& Allen, B. (2010). Employee responses to "high performance work system practices: An empirical test of the disciplined worker thesis'. Work Employment Society, 24, 740-60.

Hatton, C., Emerson, E., Rivers, M., Mason, H., Swarbrick, R., Mason, L. \& Alborz, A. (2001). Factors associated with intended staff turnover and job search behavior in services for people with intellectual disability. Journal of Intellectual Disability Research, 45(3), 258-270.

Hayes, A. F. (2013). Introduction to mediation, moderation, and conditional process analysis: A regression-based approach. New York: Guilford Press.

Hobfoll, S. E. (2001). The influence of culture, community, and the nested self in the stress process: advancing conservation of resources theory. Applied psychology, 50(3), 337-421.

Hobfoll, S., \& Freedy, J. (1993). Conservation of resources: a general stress theory applied to burnout', in W.B. 
Schaufeli, C. Maslach and T. Marek (eds), Professional

Burnout: Recent Developments in Theory and Research, New York: Taylor and Francis.

Hobfoll, S.E. (1989). Conservation of resources: a new attempt at conceptualizing stress", American Psychologist, 44(3), 513-524.

Hobfoll, S. E., Shirom, A., \& Golembiewski, R. (2000). Conservation of resources theory. appears in Handbook of Organizational Behavior, RT Golembiewski (ed.), Marcel Dekker, New York, 57-80.

Hom, P.W., Caranikas-Walker, F., Prussia, G.E., \& Griffeth, R.W. (1992). A meta analytic structural equations analysis of a model of employee turnover. Journal of Applied Psychology, 77, 890-909.

Hooft E. A. V., Born, M. P., Taris, T. W., Flier, H. V. D., \& Blonk, R. W. (2004). Predictors of job search behavior among employed and unemployed people. Personnel Psychology, 57(1), 25- 59.

Huselid, M. A. (1995). The impact of human resource management practices on turnover, productivity, and corporate financial performance. Academy of management journal, 38(3), 635-672.

Iran population $(2018,8,28)$. Retrieved from: http://www.worldometers.info/world population/iran-population. 
Jensen, J. M., Patel, P. C., \& Messersmith, J. G. (2013). High-Performance Work Systems and Job Control Consequences for Anxiety, Role Overload, and Turnover Intentions. Journal of Management, 39(6), 1699-1724.

Jiang, K., Lepak, D. P., Hu, J., \& Baer, J. C. (2012). How does human resource management influence organizational outcomes? A meta-analytic investigation of mediating mechanisms. Academy of management Journal, 55(6), 1264-1294.

Kalmbach, H. (2015), "Blurring boundaries: aesthetics, performance, and the transformation of Islamic leadership”, Culture and Religion, Vol. 16 No. 2, pp. $160-174$.

Kanfer, R., Wanberg, C. R., \& Kantrowitz, T. M. (2001). Job search and employment: A personality-motivational analysis and meta-analytic review. Journal of Applied psychology, 86(5), 837.

Karasek, R., Brisson, C., Kawakami, N., Houtman, I., Bongers, P., \& Amick, B. (1998). The Job Content Questionnaire (JCQ): an instrument for internationally comparative assessments of psychosocial job characteristics. Journal of occupational health psychology, 3(4), 322.

Karim, N.H.A., \& Noor, N.H.N.M. (2017). Evaluating the psychometric properties of Allen and Meyer's organizational commitment scale: a cross cultural application among Malaysian academic librarians”, Malaysian Journal of Library \& Information Science, 11(1), 89-101. 
Khan, A.S., \& Rasheed, F. (2015). Human resource management practices and project success, a moderating role of Islamic work ethics in Pakistani project based organizations”, International Journal of Project Management, 33(2), $435-445$.

Khatri, N. (2000). Managing human resource for competitive advantage: a study of companies in Singapore. International Journal of Human Resource Management, 11(2), 336-365.

Kish, L. (1965). Survey sampling (No. 04; HN29, K5.)

Kline, R. B. (1998). Structural equation modeling.

Kline, R. B. (2005). Principles and practice of structural equation modeling 2nd. New York: Guilford.

Kooij, D. T., Jansen, P. G., Dikkers, J. S., \& De Lange, A. H. (2010). The influence of age on the associations between HR practices and both affective commitment and job satisfaction: A meta-analysis. Journal of Organizational Behavior, 31(8), 1111-1136.

Kroon, B., Van de Voorde, K., \& Van Veldhoven, M. (2009). Cross-level effects of high performance work practices on burnout: two counteracting mediating mechanisms compared. Personnel Review, 38(5), 509-525. 
Kumar, V. (2000). International marketing research (pp. 225-226). Upper Saddle River, NJ: Prentice Hall.

Kundu, S. C., \& Gahlawat, N. (2016). High performance work systems and employees' intention to leave: Exploring the mediating role of employee outcomes. Management Research Review, 39(12), 1587-1615.

Landy, F. J., \& Conte, J. M. (2007). Work in the 21st century: An introduction to industrial organizational psychology (2nd ed.). Malden, MA: Blackwell.

Lee, T. W., \& Mitchell, T. R. (1994). An alternative approach: The unfolding model of voluntary employee turnover. Academy of Management Review, 19, 51-89.

Leong, L. Y., Hew, T. S., Lee, V. H., \& Ooi, K. B. (2015). An SEM-artificial neural-network analysis of the relationships between SERVPERF, customer satisfaction and loyalty among low-cost and full-service airline. Expert Systems with Applications, 42(19), 6620-6634.

Lepak, D. P., Liao, H., Chung, Y., \& Harden, E. E. (2006). A conceptual review of human resource management systems in strategic human resource management research. In Research in personnel and human resources management (pp. 217-271). Emerald Group Publishing Limited.

Liao, H., Toya, K., Lepak, D. P., \& Hong, Y. 2009. Do they see eye to eye? Management and employee perspectives of high-performance work systems 
and influence processes on service quality. Journal of Applied Psychology,94, 371-391.

Locke, E. (1976). The nature and causes of job satisfaction. Handbook of Industrial and Organizational Psychology, 1, 1297-1343.

Luther, N. (2000). Integrity Testing and Job Performance Within High Performance Work Teams: A Short Note. Journal of Business and Psychology 15(1), 1925. https://doi.org/10.1023/A:1007762717488.

MacDuffie J. P. 1995. Human resource bundles and manufacturing performance: Organizational logic and flexible production systems in the world auto industry. Industrial and Labor Relations Review, 48, 197-221.

March, J. G., \& Simon, H. A. (1958). Organizations.

Miller, L. E., \& Smith, K. L. (1983). Handling nonresponse issues. Journal of extension, $21,45-50$.

Mobley, W. H., Griffeth, R. W., Hand, H. H., \& Meglino, B. M. (1979). Review and conceptual analysis of the employee turnover process. Psychological bulletin, 86(3), 493.

Mostafa, A. M. S. (2017). High-performance HR practices, positive affect and employee outcomes. Journal of Managerial Psychology, 32(2), 163-176. 
Namazie, P., \& Frame, P. (2007). Developments in human resource management in Iran. The International Journal of Human Resource Management, 18(1), 159171.

Namazie, P., \& Tayeb, M. (2006). Human resource management in Iran. Managing human resources in the Middle East, 20-39.

Nederhof, A. J. (1985). Methods of coping with social desirability bias: A review. European. journal of social psychology, 15(3), 263-280.

Netemeyer, R.G., Boles, J.S., McKee, D.O., \& McMurrian, R. (1997). An investigation into the antecedents of organizational citizenship behaviors in a personal selling concept. Journal of Marketing, 61(3), 85-98.

Nunally, J. C., \& Bernstein, I. H. (1978). Psychometric theory.

Osterman, P. (1994). How common is workplace transformation and who adopts it? ILR Review, 47(2), 173-188.

Page, S. J., Bentley, T., Teo, S., \& Ladkin, A. (2018). The dark side of high performance human resource practices in the visitor economy. International Journal of Hospitality Management, 74, 122-129.

Paloutzian, R.F., \& Park, C.L. (2014), Handbook of the Psychology of Religion and Spirituality, Guilford Publications. 
Peccei, R. E., Van de Voorde, F. C., Van Veldhoven, M. J. P. M., Paauwe, J., Guest, D. E., \& Wright, P. M. (2013). HRM, well-being and performance: A theoretical and empirical review. HRM \& performance, 15-46.

Pfeffer, J., \& Jeffrey, P. (1998). The human equation: Building profits by putting people first. Harvard Business Press.

Podsakoff, P. M., MacKenzie, S. B., \& Podsakoff, N. P. (2012). Sources of method bias in social science research and recommendations on how to control it. Annual review of psychology, 63, 539-569.

Podsakoff, P. M., MacKenzie, S. B., Lee, J. Y., \& Podsakoff, N. P. (2003). Common method biases in behavioral research: A critical review of the literature and recommended remedies. Journal of applied psychology, 88(5), 879.

Porter, M. E., \& Strategy, C. (1980). The Free Press. New York.

Posthuma, R. A., Campion, M. C., Masimova, M., \& Campion, M.A. (2013). High performance work practices taxonomy: Integrating the literature and directing future research. Journal of Management, 39(5), 1184-1220.

Preacher, K. J., \& Hayes, A. F. (2004). SPSS and SAS procedures for estimating indirect effects in simple mediation models. Behavior Research Methods, Instruments, \& Computers, 36, 717-731. 
Preacher, K. J., Rucker, D. D., \& Hayes, A. F. (2007). Addressing moderated mediation hypotheses: Theory, methods, and prescriptions. Multivariate behavioral research, 42(1), 185-227.

Punnett, B. J. (2015). International perspectives on organizational behavior and human resource management. Routledge.

Purcell, J., \& Hutchinson, S. (2007). Front- line managers as agents in the HRM- performance causal chain: theory, analysis and evidence. Human Resource management journal, 17(1), 3-20.

Rabl, T., Jayasinghe, M., Gerhart, B. and Kühlmann, T. M. 2014. A meta-analysis of country differences in the high-performance work system - business performance relationship: The roles of national culture and managerial discretion. Journal of Applied Psychology, 99(6), p.1011.

Ramadani, V., Dana, L.P., Gërguri-Rashiti, S., \& Ratten, V. (2017). An introduction to entrepreneurship and management in an Islamic context. Entrepreneurship and Management in an Islamic Context, Springer International Publishing, pp. $1-5$.

Ramsay, H., Scholarios, D., \& Harley, B. (2000). Employees and high- performance work systems: Testing inside the black box. British Journal of industrial relations, 38(4), 501-531. 
Rees A. (1966). Labor economics: Effects of more knowledge-information networks in labor markets. American Economic Review, 56,559-566.

Reuss, C. F. (1943). Differences between persons responding and not responding to a mailed questionnaire. American Sociological Review, 433-438.

Robert, C., Probst, T. M., Martocchio, J. J., Drasgow, F., \& Lawler, J. J. (2000). Empowerment and continuous improvement in the United States, Mexico, Poland, and India: Predicting fit on the basis of the dimensions of power distance and individualism. Journal of applied psychology, 85(5), 643.

Rosenfeld, C. (1977). The extent of job search by employed workers. US Department of Labor, Bureau of Labor Statistics.

Rucker, D. D., Preacher, K. J., Tormala, Z. L., \& Petty, R. E. (2011). Mediation analysis in social psychology: Current practices and new recommendations. Social and Personality Psychology Compass, 5(6), 359-371.

Saridakis, G., Lai, Y. and Cooper, C. L. 2017. Exploring the relationship between HRM and firm performance: A meta-analysis of longitudinal studies. Human Resource Management Review, 27(1), pp.87-96.

Saunders, M., Lewis, P., \& Thornhill, A. (2009). Research methods for business students (5 uppl.). Harlow: Pearson education limited. 
Schwab, D. P., Rynes, S. L., \& Aldag, R. J. (1987). Theories and research on job search and choice. Research in personnel and human resources management, $5(1), 129-166$.

Sheehan, M. (2014). Human resource management and performance: Evidence from small and medium-sized firms. International Small Business Journal, 32(5), $545-570$.

Shrout, P. E., \& Bolger, N. (2002). Mediation in experimental and nonexperimental studies: new procedures and recommendations. Psychological methods, 7(4), 422.

Sim, J. J., Tan, G. W. H., Wong, J. C., Ooi, K. B., \& Hew, T. S. (2014). Understanding and predicting the motivators of mobile music acceptance-a multi-stage MRA-artificial neural network approach. Telematics and Informatics, 31(4), 569-584.

Smith, C. L., \& Gerhart, B. (1991). The impact of job search strategy and interviewer assessments of employ ability on multiple measures of labor marker success. In Academy of Management Meetings.

Sparham, E., \& Sung, J. (2007). High Performance Work Practices: Work Intensification or'Win-win'?.

Steffy, B. D., Shaw, K. N., \& Noe, A. W. (1989). Antecedents and consequences of job search behaviors. Journal of Vocational Behavior, 35(3), 254-269. 
Sun, L. Y., Aryee, S. and Law, K. (2007). High performance human resource management practices, citizenship behavior, and organizational performance: a relational perspective. Academy of Management Journal, 50, 558-77.

Tanova, C., \& Holtom, B. C. (2008). Using job embeddedness factors to explain voluntary turnover in four European countries. The International Journal of Human Resource Management, 19(9), 1553-1568.

Taylor, I., Walton, P., \& Young, J. (2013). The new criminology: For a social theory of deviance. Routledge.

Theorell, T., \& Karasek, R. A. (1996). Current issues relating to psychosocial job strain and cardiovascular disease research. Journal of occupational health psychology, 1(1), 9 .

Van De Voorde, K., \& Beijer, S. (2014). The role of employee HR attributions in the relationship between high-performance work systems and employee outcomes. Human Resource Management Journal, 25(1), 67-78.

Van De Voorde, K., Paauwe, J., \& Van Veldhoven, M. (2012). Employee well- being and the HRM-organizational performance relationship: a review of quantitative studies. International Journal of Management Reviews, 14(4), 391-407.

Walton, E. J. (2005). The persistence of bureaucracy: A meta-analysis of Weber's model of bureaucratic control. Organization Studies, 26(4), 569-600 
Wen, J., Meng, F., Ying, T., Qi, H., \& Lockyer, T. (2018). Drug tourism motivation of Chinese outbound tourists: Scale development and validation. Tourism Management, 64, 233-244.

Wood, S., Van Veldhoven, M., Croon, M., \& de Menezes, L. M. (2012). Enriched job design, high involvement management and organizational performance: The mediating roles of job satisfaction and well-being. Human relations, 65(4), 419-445.

Wu, P. C. and Chaturvedi, S. 2009. The role of procedural justice and power distance in the relationship between high performance work systems and employee attitudes: pp.1228-1247. multilevel perspective. Journal of Management, $35(5)$,

Xanthopoulou D., Bakker A.B., Dollard M.F., Demerouti E., Schaufeli W.B., Taris T.W. \& Schreurs P.J.G. (2007). When do job demands particularly predict burnout? The moderating role of job resources. Journal of Managerial Psychology, 22(8), 766- 786

Yi, C., \& Yan, A. (2018). Research on High Performance Work Systematic Influences on Employees Work Behaviour in Environmental Company. Ekoloji, 27(106), 337-349. 


\section{APPENDICES}




\section{Appendix A: English Questionnaire}

\section{Dear respondent,}

You are kindly requested to fill out this questionnaire in a self-administered manner. Please note that there are no right or wrong answers, and the information you provide will be kept strictly confidential. We appreciate your time and participation in this research.

\begin{tabular}{|l|c|c|c|c|c|}
\hline \multicolumn{1}{|c|}{ Assessment scale: } & $\begin{array}{c}* \\
\text { Strongly } \\
\text { disagree }\end{array}$ & $\begin{array}{c}\text { Disa } \\
\text { gree }\end{array}$ & $\begin{array}{c}(-) \\
\text { Indiffer } \\
\text { ence }\end{array}$ & $\begin{array}{c}\text { Agr } \\
\text { ee }\end{array}$ & Strongly agree \\
\hline $\begin{array}{l}\text { Please read each statement carefully } \\
\text { and indicate your response by placing } \\
\text { a circle or tick }\end{array}$ & 1 & 2 & 3 & 4 & 5 \\
\hline
\end{tabular}

\section{HPWS}

\begin{tabular}{|c|c|c|c|c|c|c|}
\hline 1 & $\begin{array}{l}\text { In my workplace, great effort is taken to select the } \\
\text { right person }\end{array}$ & 1 & 2 & 3 & 4 & 5 \\
\hline 2 & $\begin{array}{l}\text { In my workplace, long-term employee potential is } \\
\text { emphasized. }\end{array}$ & 1 & 2 & 3 & 4 & 5 \\
\hline 3 & $\begin{array}{l}\text { In my workplace, considerable importance is placed } \\
\text { on the staffing process. }\end{array}$ & 1 & 2 & 3 & 4 & 5 \\
\hline 4 & $\begin{array}{l}\text { In my workplace, very extensive efforts are made in } \\
\text { selection. }\end{array}$ & 1 & 2 & 3 & 4 & 5 \\
\hline 5 & $\begin{array}{l}\text { In my workplace, extensive training programs are } \\
\text { provided for individuals in customer contact or front- } \\
\text { line jobs. }\end{array}$ & 1 & 2 & 3 & 4 & 5 \\
\hline 6 & $\begin{array}{l}\text { Employees in customer contact jobs will normally go } \\
\text { through training programs every few years. }\end{array}$ & 1 & 2 & 3 & 4 & 5 \\
\hline 7 & $\begin{array}{l}\text { There are formal training programs to teach new hires } \\
\text { the skills they need to perform their job. }\end{array}$ & 1 & 2 & 3 & 4 & 5 \\
\hline 8 & $\begin{array}{l}\text { Formal training programs are offered to employees in } \\
\text { order to increase their promot ability in this } \\
\text { organization. }\end{array}$ & 1 & 2 & 3 & 4 & 5 \\
\hline
\end{tabular}
9 Employees have few opportunities for upward $\quad \begin{array}{lllll}1 & 2 & 3 & 4 & 5\end{array}$ mobility. (reverse-coded)
10 Employees do not have any future in this $\quad \begin{array}{lllll}1 & 2 & 3 & 4 & 5\end{array}$ organization. (reverse-coded)

11 Promotion in this organization is based on seniority. $\quad \begin{array}{lllll}1 & 2 & 3 & 4 & 5\end{array}$ (reverse-coded)

12 Employees have clear career paths in this organization.

13 Employees in customer contact jobs who desire promotion have more than one potential position they 
could be promoted to.

14 Employees in this job can be expected to stay with $\quad \begin{array}{lllll}1 & 2 & 3 & 4 & 5\end{array}$

this organization for as long as they wish.

15 Job security is almost guaranteed to employees in $\quad \begin{array}{lllll}1 & 2 & 3 & 4 & 5\end{array}$ this job.

$\begin{array}{lllll}1 & 2 & 3 & 4 & 5\end{array}$

17 This job has an up-to-date description. $\quad \begin{array}{lllll}1 & 2 & 3 & 4 & 5\end{array}$

18 The job description for a position accurately describes $\begin{array}{llllll}1 & 2 & 3 & 4 & 5\end{array}$ all of the duties performed by individual employees.

19 Performance is more often measured with objective $\begin{array}{llllll}1 & 2 & 3 & 4 & 5\end{array}$ quantifiable results.

20 Performance appraisals are based on objective quantifiable results.

21 Employee appraisals emphasize long term and $\quad \begin{array}{lllll}1 & 2 & 3 & 4 & 5\end{array}$ group-based achievement.

22 Individuals in this job receive bonuses based on the $\begin{array}{llllll}1 & 2 & 3 & 4 & 5\end{array}$ profit of the organization.

23 Close tie or matching of pay to individual/group $\quad \begin{array}{lllll}1 & 2 & 3 & 4 & 5\end{array}$ performance.

24 Employees in this job are often asked by their $\quad \begin{array}{lllll}1 & 2 & 3 & 4 & 5\end{array}$ supervisor to participate in decisions.

25 Individuals in this job are allowed to make decisions. $\begin{array}{lllll}1 & 2 & 3 & 4 & 5\end{array}$

26 Employees are provided the opportunity to suggest $\quad \begin{array}{llllll}1 & 2 & 3 & 4 & 5\end{array}$ improvements in the way things are done.

27 Supervisors keep open communications with $\quad \begin{array}{lllll}1 & 2 & 3 & 4 & 5\end{array}$ employees in this job.

\begin{tabular}{|l|c|c|c|c|c|c|}
\hline \multicolumn{1}{|c|}{ Assessment scale: } & $\begin{array}{c}* \\
\text { Strongly } \\
\text { disagree }\end{array}$ & $\begin{array}{c}\text { Disagr } \\
\text { ee }\end{array}$ & $\begin{array}{c}\text { Somewh } \\
\text { at } \\
\text { disagree }\end{array}$ & $\begin{array}{c}\text { Somewhat } \\
\text { agree }\end{array}$ & agree & $\begin{array}{c}\text { Strongl } \\
\text { y agree }\end{array}$ \\
\hline $\begin{array}{l}\text { Please read each statement carefully } \\
\text { and indicate your response by } \\
\text { placing a circle or tick }\end{array}$ & 1 & 2 & 3 & 4 & 5 & 6 \\
\hline
\end{tabular}


PSYCAPT-24 items

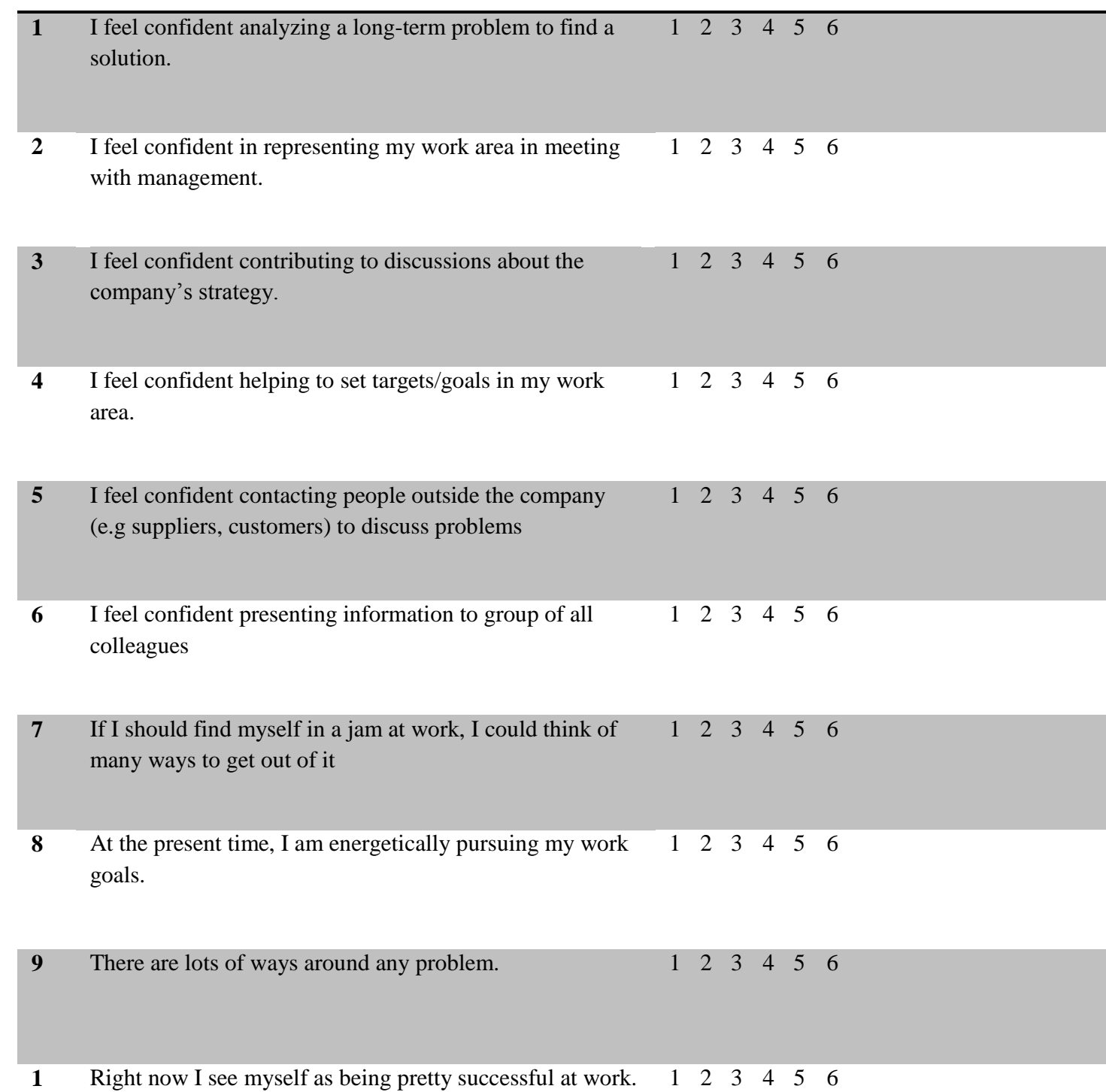

11 I can think of many ways to reach my current work goals. $\begin{array}{llllll}1 & 2 & 3 & 4 & 5 & 6\end{array}$

12 At this time, I am meeting the work goals that I have set $\begin{array}{llllll}1 & 2 & 3 & 4 & 5 & 6\end{array}$ for myself.

13 When I have a setback at work, I have trouble recovering $\quad \begin{array}{lllllll}1 & 2 & 3 & 4 & 5 & 6\end{array}$ from it, moving on. ${ }^{\circledR}$

14 I usually manage difficulties one way or another at work. $\begin{array}{lllllll}1 & 2 & 3 & 4 & 5 & 6\end{array}$ 


\begin{tabular}{|c|c|c|c|c|c|c|c|}
\hline 15 & I can be "on my own," so to speak, at work if I have to. & 1 & $\overline{2}$ & 3 & $\overline{4}$ & 5 & 6 \\
\hline 16 & I usually take stressful things at work in stride. & 1 & 2 & 3 & 4 & 5 & 6 \\
\hline 17 & $\begin{array}{l}\text { I can get through difficult times at work because I've } \\
\text { experienced difficulty before. }\end{array}$ & 1 & 2 & 3 & 4 & 5 & 6 \\
\hline 18 & I feel I can handle many things at a time at this job. & 1 & 2 & 3 & 4 & 5 & 6 \\
\hline 19 & $\begin{array}{l}\text { When things are uncertain for me at work, I usually } \\
\text { expect the best. }\end{array}$ & 1 & 2 & 3 & 4 & 5 & 6 \\
\hline 20 & If something can go wrong for me work-wise, it will.(R) & 1 & 2 & 3 & 4 & 5 & 6 \\
\hline 21 & $\begin{array}{l}\text { I always look on the bright side of things regarding my } \\
\text { job. }\end{array}$ & 1 & 2 & 3 & 4 & 5 & 6 \\
\hline 22 & $\begin{array}{l}\text { I'm optimistic about what will happen to me in the future } \\
\text { as it pertains to work. }\end{array}$ & 1 & 2 & 3 & 4 & 5 & 6 \\
\hline 23 & $\begin{array}{l}\text { In this job, things never work out the way I want them to } \\
\text { (R) }\end{array}$ & 1 & 2 & 3 & 4 & 5 & 6 \\
\hline 24 & I approach This job as if "every could has a silver lining". & 1 & 2 & 3 & 4 & 5 & 6 \\
\hline
\end{tabular}




\begin{tabular}{|l|c|c|c|c|c|}
\hline \multicolumn{1}{|c|}{ Assessment scale: } & never & seldom & sometimes & often & Almost \\
\hline & & & & \\
\hline $\begin{array}{l}\text { Please read each statement carefully and } \\
\text { indicate your response by placing a } \\
\text { circle or tick }\end{array}$ & 1 & 2 & 3 & 4 & 5 \\
\hline
\end{tabular}

JSB: How much time have you spent in the last four months on several preparatory and active job search activities?

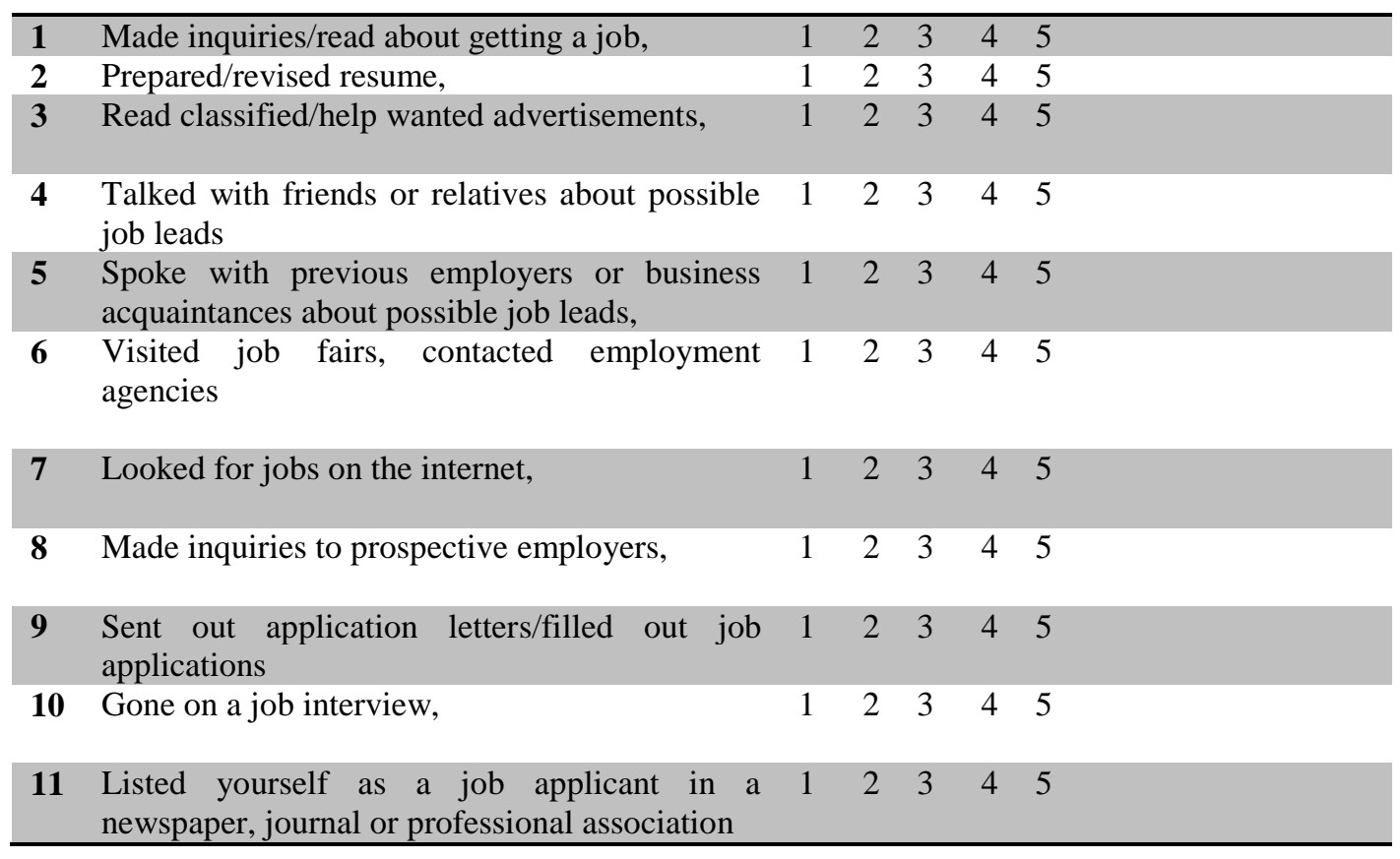




\begin{tabular}{|l|c|c|c|c|c|}
\hline \multicolumn{1}{|c|}{ Assessment scale: } & Strongly & Disag & Indiffere & Agr & Strongly \\
\hline disagree & ree & nce & ee & agree \\
\hline $\begin{array}{l}\text { Please read each statement carefully } \\
\text { and indicate your response by placing a } \\
\text { circle or tick }\end{array}$ & 1 & 2 & 3 & 4 & 5 \\
\hline
\end{tabular}

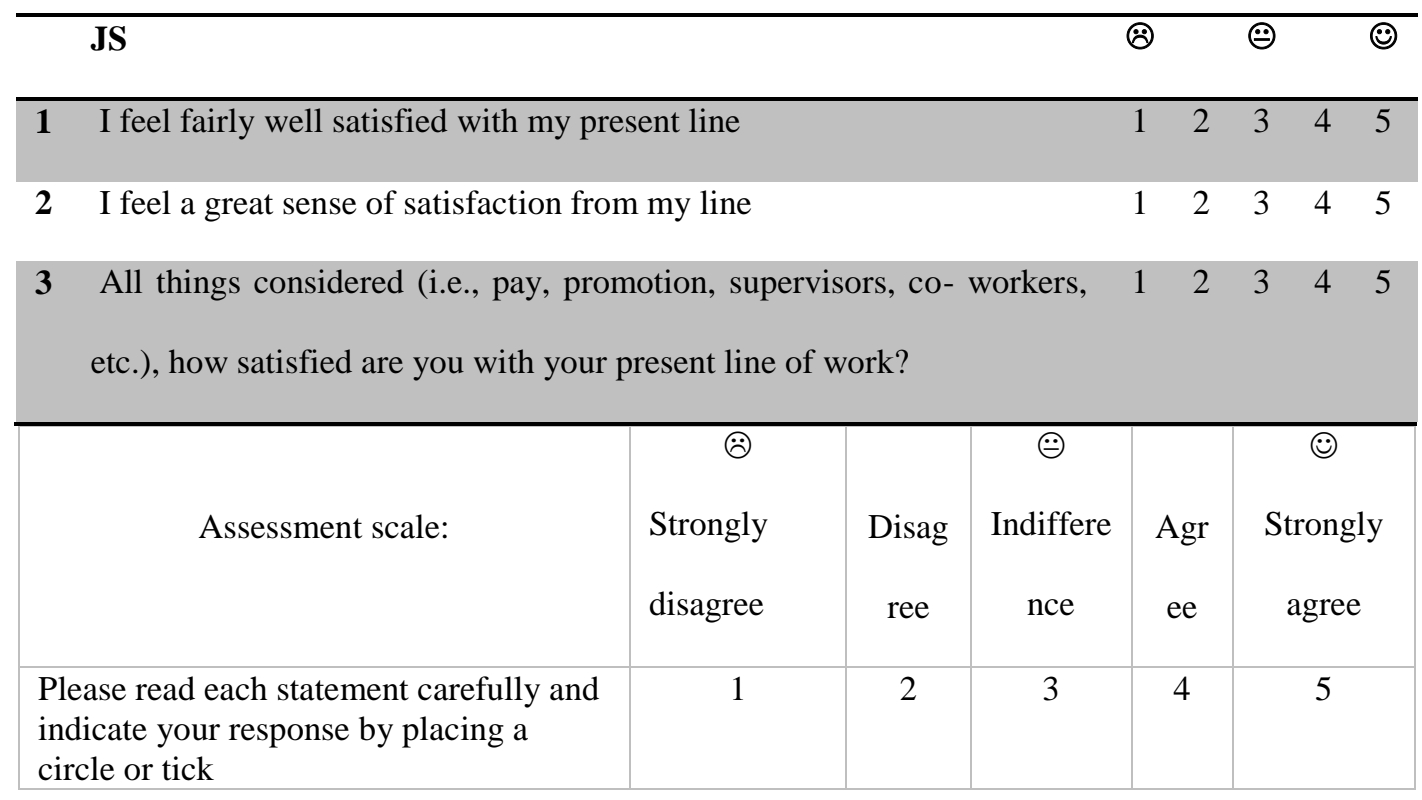

\begin{tabular}{|c|c|c|c|c|c|c|}
\hline & PSY-JD & (2) & & ;) & & (;) \\
\hline 1 & My job requires working very hard. & 1 & 2 & 3 & 4 & 5 \\
\hline 2 & I have enough time to get the job down. & 1 & 2 & 3 & 4 & 5 \\
\hline 3 & $\begin{array}{l}\text { My tasks are often interrupted before they can be completed, requiring } \\
\text { attention at a later time. }\end{array}$ & 1 & 2 & 3 & 4 & 5 \\
\hline 4 & My job requires long periods of intense concentration on the task. & 1 & 2 & 3 & 4 & 5 \\
\hline 5 & I am not asked to do an excessive amount of work. & 1 & 2 & 3 & 4 & 5 \\
\hline 6 & My job is very hectic. & 1 & 2 & 3 & 4 & 5 \\
\hline 7 & $\begin{array}{l}\text { Waiting on work from other people or departments often slows me } \\
\text { down on my job. }\end{array}$ & 1 & 2 & 3 & 4 & 5 \\
\hline
\end{tabular}


Demographics - Kindly place a thick $(\checkmark)$ in the appropriate alternatives.

1. Your gender?

$$
\text { Male [ ] Female [ ] }
$$

2. How old are you?

$$
\text { Under } 20 \text { [ ] 21-30 [ ] 31-40 [ ] 41-50 [ ] Over 51 [] }
$$

3. What is your marital status?

$$
\text { Single [ ] Married [ ] }
$$

4. What is your monthly income?

$$
\begin{aligned}
& \text { Under } 1 \text { milion Toman [ ] } \\
& 1-1.99 \text { milion Toman [ ] } \\
& 2-2.49 \text { milion Toman [ ] } \\
& 2.5 \text { - } 3 \text { milion Toman [ ] } \\
& \text { Above } 3 \text { milion Toman [ ] }
\end{aligned}
$$

5. What is your level of education?

$$
\text { Middle School [] High School [ ] Some College [ ] Bachelor's Degree [ ] }
$$

Higher Degree [ ]

6. Please indicate the number of years you have been working in this organization?

$$
\text { Less than } 1 \text { year [ ] } 1 \text { - } 4 \text { years [ ] } 5-8 \text { years [ ] } 9 \text { years and above [ ] }
$$




\section{Appendix B: Persian Questionnaire}

\begin{tabular}{|c|c|c|c|c|c|}
\hline$\stackrel{3}{3}_{3}^{3}$ & 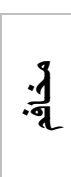 & $\begin{array}{l}\text { 羿 } \\
\underbrace{\frac{7}{2}}\end{array}$ & 脑 & 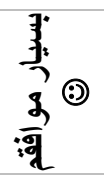 & \\
\hline & & & & & در محل كار من، براى انتخاب صحيح افر اد تلاش فر او انى \\
\hline & & & & & در محل كار من، بر استخدام بلندمدت تاكيد مى شود. \\
\hline & & & & & ديكيرد. دمل كارمن، اهميت قابل توجهى به استخدام افر اد صورت \\
\hline & & & & & ديكيرد. محل كارمن،تلاش بسيارى در انتخاب افراد صورت \\
\hline & & & & & 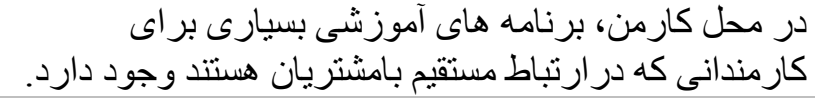 \\
\hline & & & & & 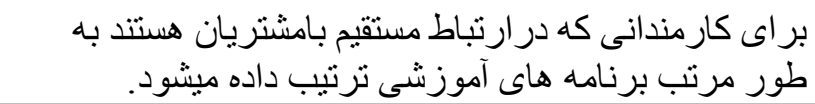 \\
\hline & & & & & 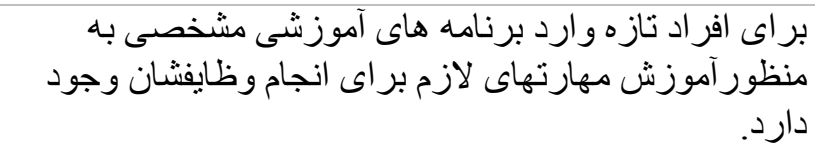 \\
\hline & & & & & 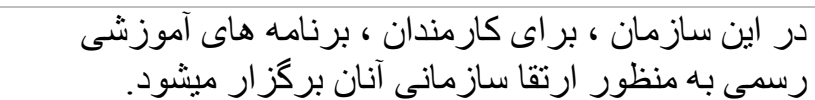 \\
\hline & & & & & كاركنان از شانس كمى بر ایى ارتقاء شغلى برخوردار هستند. \\
\hline & & & & & كاركنان هيج آينده شغلى در اين سازمان ندارند. \\
\hline & & & & & ارتقاء شغلى در اين سازمان بر اساس سابقه كارى مى باتثد. \\
\hline & & & & & درتند. سازمان، كارمندان دار اى مسير هاى شغلى مشخصى \\
\hline & & & & & 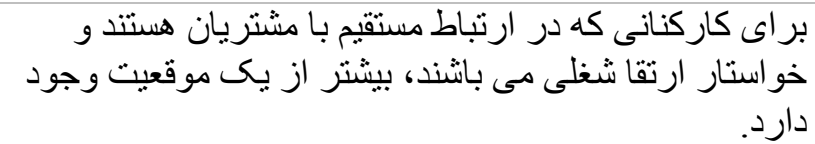 \\
\hline & & & & & كارمندان ميتو انند تازمانى كه خودشان مايل باشند، در اين \\
\hline & & & & & امنيت شغلى براى كاركنان تقريبا تضمين شده است. \\
\hline & & & & & شرح وظايف كارى به وضوح تعريف شده است. \\
\hline & & & & & شرح وظايف كارى مدام به روز رسانى ميشوند. \\
\hline & & & & & 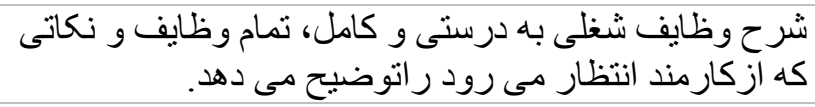 \\
\hline & & & & & عملكرد افر اد اغلب بامعيار هاى عينى ، سنجيده ميشود. \\
\hline
\end{tabular}




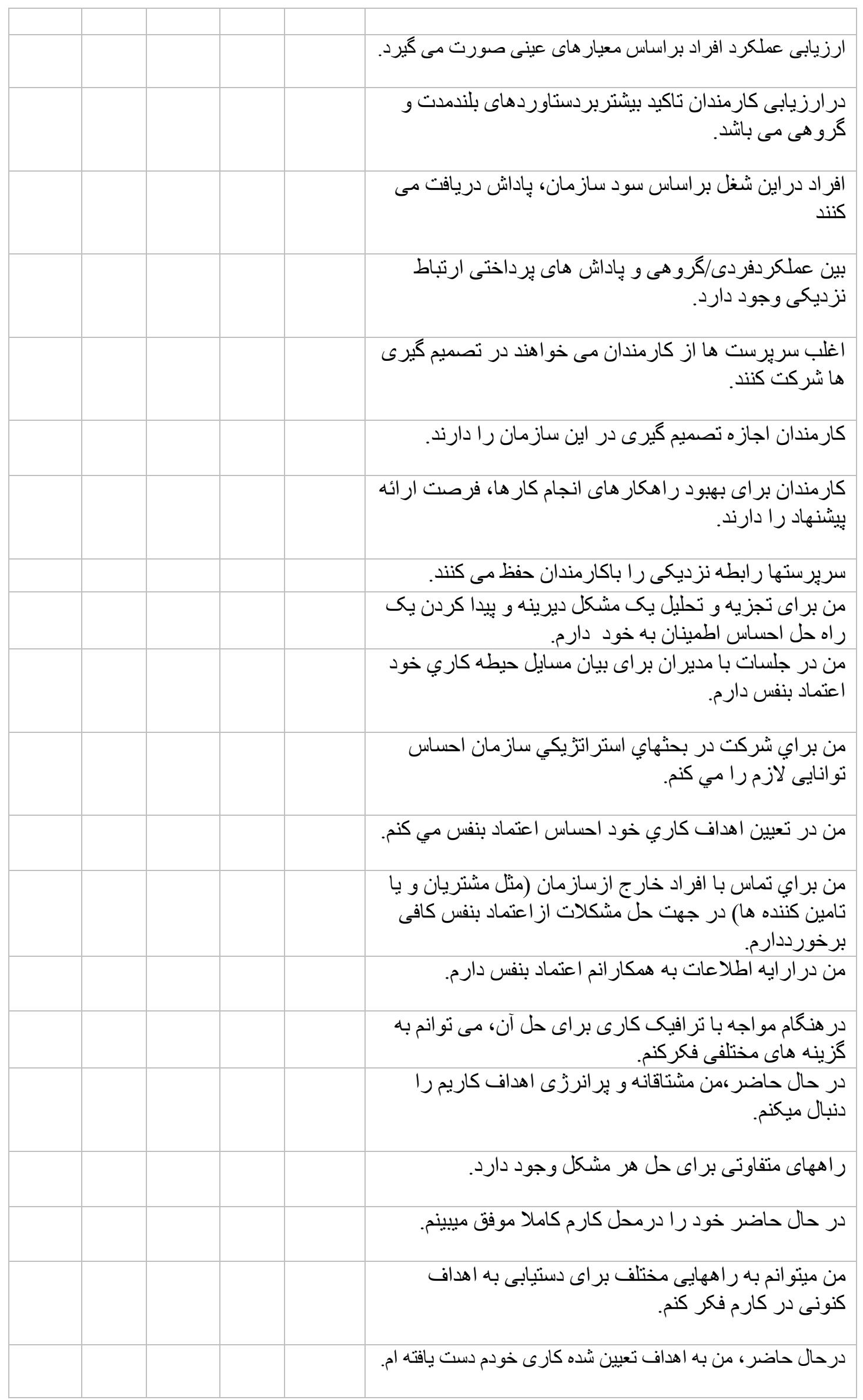




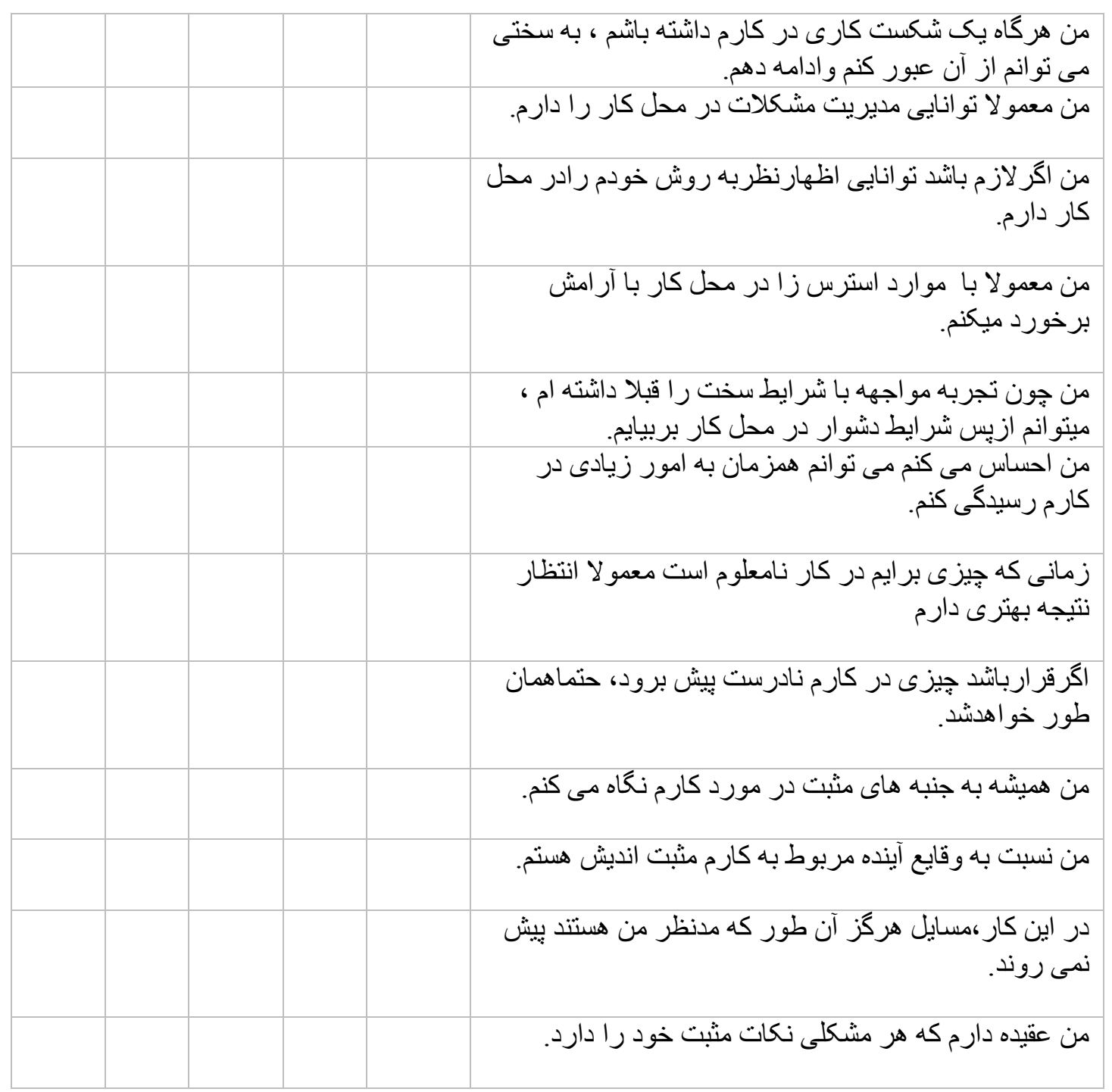




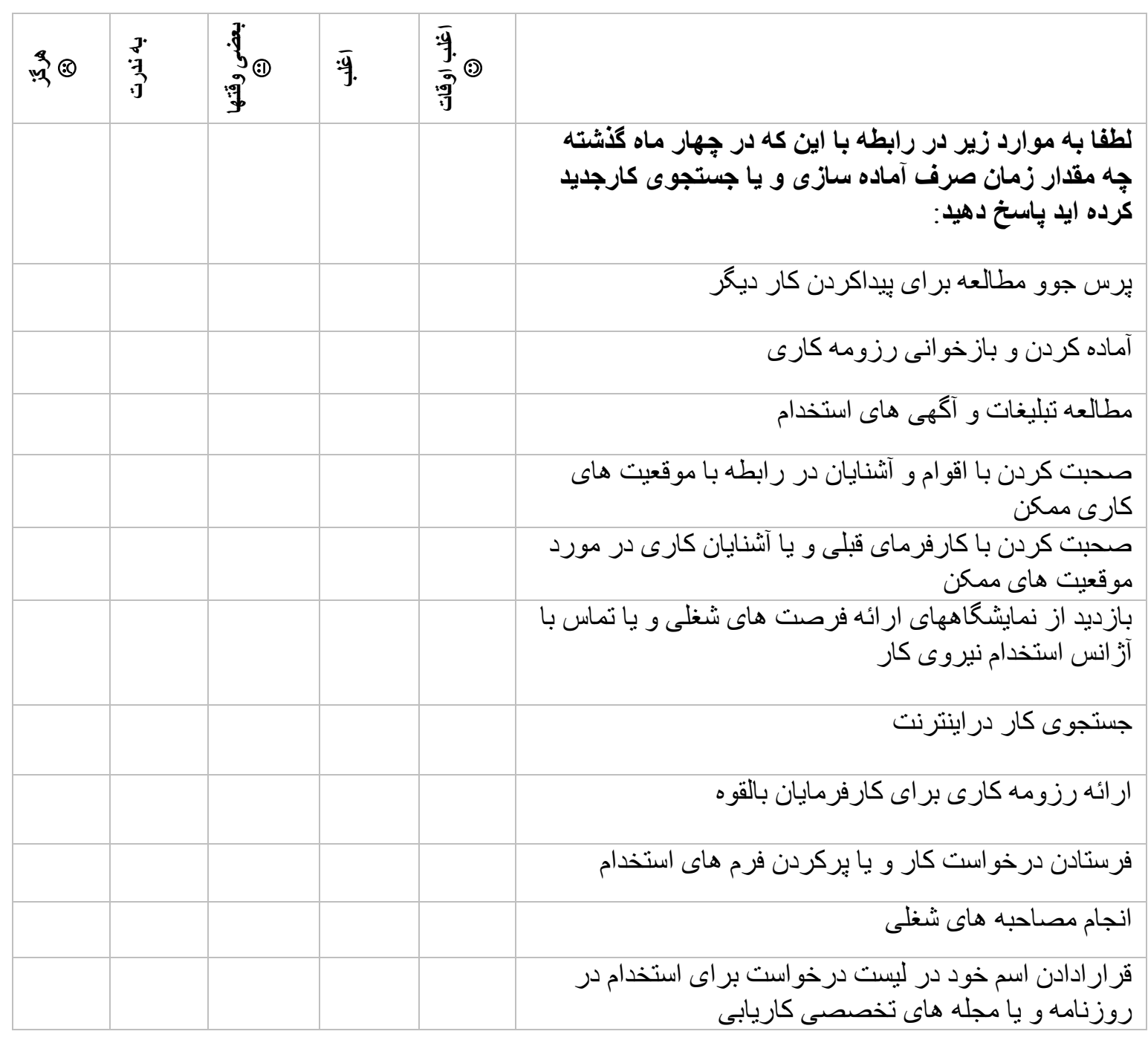




\begin{tabular}{|c|c|c|c|c|c|}
\hline$\stackrel{3}{3} \cdot \stackrel{3}{3}$ & ·ู่ & $\begin{array}{l}\text { 年 } \\
\frac{7}{2} \\
\frac{7}{2}\end{array}$ & 泫 & $\begin{array}{l}\text { 承: } \\
\frac{3}{3}\end{array}$ & \\
\hline & & & & & من از مسير فعلى خود احساس رضايت كافى مى كنم \\
\hline & & & & & من از مسير فعلى خود بسيار احساس رضايت مى كنم \\
\hline
\end{tabular}

\begin{tabular}{|c|c|c|c|c|c|}
\hline 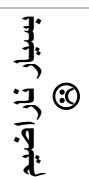 & $\frac{\overrightarrow{3}}{\sqrt{9}}$ & $\begin{array}{l}-7 \\
y \\
\frac{7}{2}\end{array}$ & 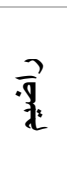 & 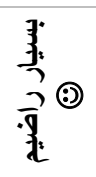 & \\
\hline & & & & & 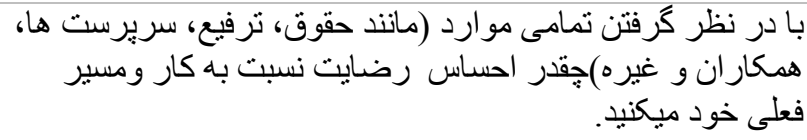 \\
\hline
\end{tabular}

\begin{tabular}{|c|c|c|c|c|c|}
\hline$\stackrel{3}{3}$ & : & 势 & 淁 & 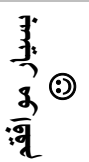 & \\
\hline & & & & & شغل من نياز به كار كردن فر او ان دارد. \\
\hline & & & & & من بر اى تكميل وبه بايان رساندن كارم زمان كافى دارم. \\
\hline & & & & & 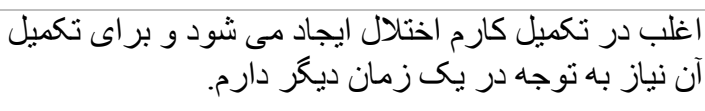 \\
\hline & & & & & شغل من نيازمند تمركز طو لانى مدت ميياتثد. \\
\hline & & & & & ازمن درخواست اضافه كارى نمى شود. \\
\hline & & & & & شغل من بسيار كيج كننده و يِيجيده مى باثند. \\
\hline & & & & & 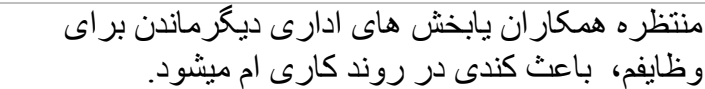 \\
\hline
\end{tabular}




$$
\text { بإسخگوى گر امى سلام، }
$$

اينجانب دانشجوى دكتر اي رشته مديريت براى تحقيق بإيان نامه خويش، بِرسشنامه زير را تدوين كرده ام. هدف تدوين اين برسشنامه، بررسى تأثّيّرات روش هاى نوين مديريت منابع انسانى بر رفتار هاى سازمانى و عملكرد افر اد ميباشد. از شما بِاسخكوى محترم خو اهشمنديم كه با مطالعه و بِاسخكويى دقيق به هر يك از سؤالات زير مار ا در انجام هر جه بهتر اين يزّو هش يارى فرماييد. به شما اين اطمينان داده ميشود كه ياسخ هاى شما كاملا محرمانه ميباشد و صرفا درجهت تحليل بزّو هش

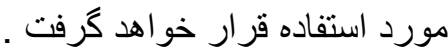
از همكارى شما صميمانه سيّاسكز اريم.

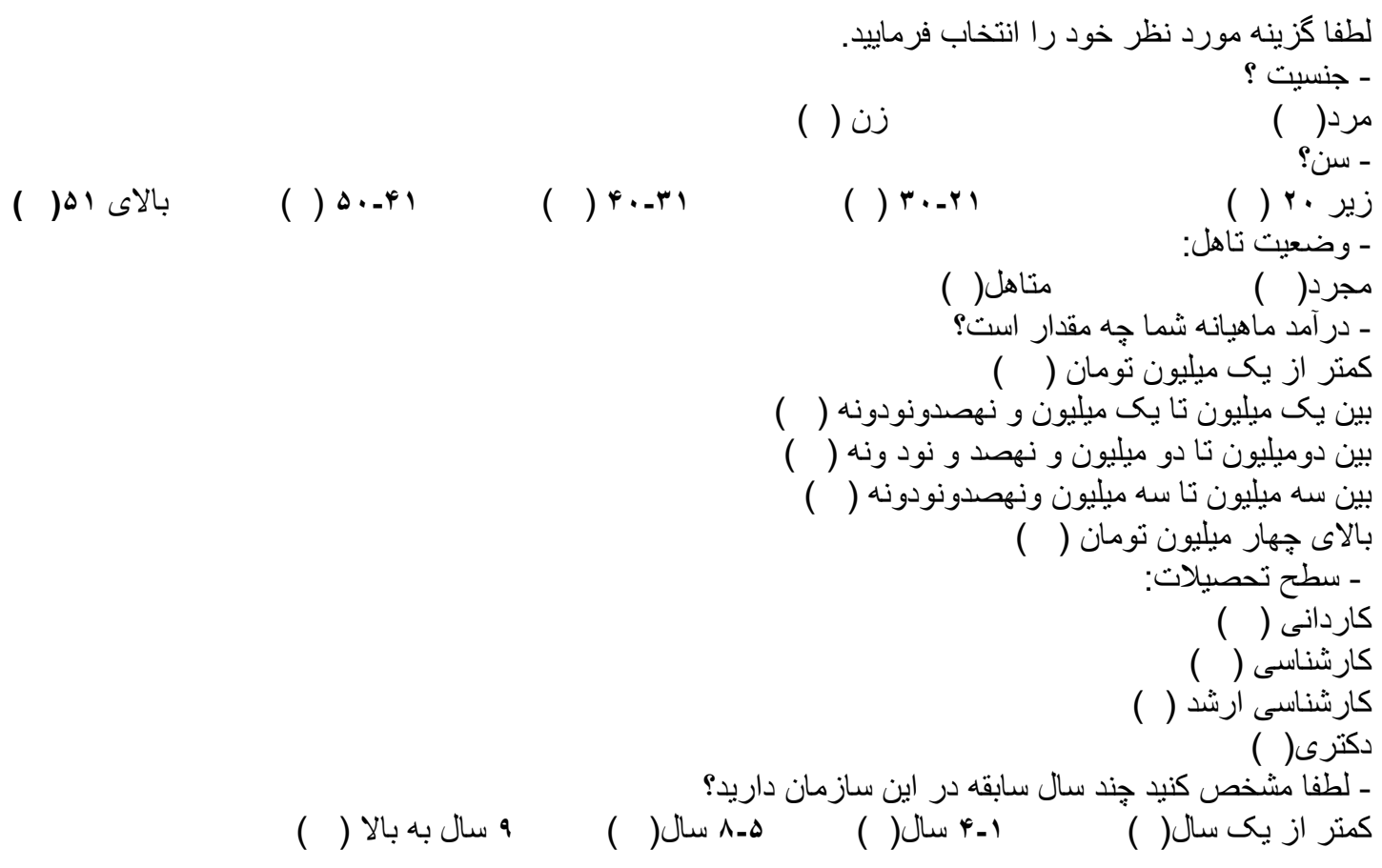

